\title{
Vitamin D and its low calcemic analogs modulate the anticancer properties of cisplatin and dacarbazine in the human melanoma A375 cell line
}

\author{
ANNA PIOTROWSKA ${ }^{1}$, JUSTYNA WIERZBICKA ${ }^{1}$, AGNIESZKA RYBARCZYK ${ }^{1}$, \\ ROBERT C. TUCKEY ${ }^{2}$, ANDRZEJ T. SLOMINSKI ${ }^{3-5}$ and MICHA£ A. ŻMIJEWSKI ${ }^{1}$
}

${ }^{1}$ Department of Histology, Faculty of Medicine, Medical University of Gdansk, 80-211 Gdansk, Poland;

${ }^{2}$ School of Molecular Sciences, Faculty of Science, The University of Western Australia, Perth, Western Australia 6009, Australia; ${ }^{3}$ Department of Dermatology; ${ }^{4}$ Comprehensive Cancer Center, Cancer Chemoprevention Program, University of Alabama at Birmingham, Birmingham, AL 35294; ${ }^{5}$ Veterans Administration Medical Center, Birmingham, AL 35233, USA

Received October 15, 2018; Accepted January 14, 2019

DOI: 10.3892/ijo.2019.4725

\begin{abstract}
Melanoma represents a significant challenge in cancer treatment due to the high drug resistance of melanomas and the patient mortality rate. This study presents data indicating that nanomolar concentrations of the hormonally active form of vitamin D, 1 $\alpha, 25$-dihydroxyvitamin D3 [1 $\left.\alpha, 25(\mathrm{OH})_{2} \mathrm{D} 3\right]$, its non-calcemic analogues 20S-hydroxyvitamin D3 and 21-hydroxypregnacalciferol, as well as the low-calcemic synthetic analog calcipotriol, modulate the efficacy of the anticancer drugs cisplatin and dacarbazine. It was observed that vitamin D analogs sensitized melanoma A375 cells to hydrogen peroxide used as an inducer of oxidative stress. On the other hand, only $1 \alpha, 25(\mathrm{OH})_{2} \mathrm{D} 3$ resulted in a minor, but significant effect on the proliferation of melanoma cells treated simultaneously with dacarbazine, but not cisplatin. Notably, cisplatin $(300 \mu \mathrm{M})$ exhibited a higher overall antiproliferative activity than dacarbazine. Cisplatin treatment of melanoma cells resulted in an induction of apoptosis as demonstrated by flow cytometry (accumulation of cells at the $\mathrm{subG}_{1}$ phase of
\end{abstract}

Correspondence to: Professor Michał A. Żmijewski, Department of Histology, Faculty of Medicine, Medical University of Gdansk, 1a Debinki Street, 80-211 Gdansk, Poland

E-mail: mzmijewski@gumed.edu.pl

Abbreviations: $1 \alpha, 25(\mathrm{OH})_{2} \mathrm{D} 3,1 \alpha, 25$-dihydroxyvitamin $\mathrm{D} 3 ; 20(\mathrm{OH})$ D3, 20S-hydroxyvitamin D3; 21(OH)pD, 21-hydroxypregnacalciferol; 25(OH)D3, 25-hydroxyvitamin D3; CAT, catalase; CCCP, carbonyl cyanide 3-chlorophenylhydrazone; PDIA3, protein disulfide-isomerase A3; PDOX, patient-derived orthotropic xenograft; ROS, reactive oxygen species; SOD1, superoxide dismutase 1; SOD2, superoxide dismutase 2; SRB, sulphorhodamine B; UV, ultraviolet; VDR, vitamin D receptor; $\Delta \psi_{\mathrm{m}}$, mitochondrial membrane potential

Key words: vitamin D, vitamin D analogs, hydroxyvitamin D, melanoma, reactive oxygen species, oxidative stress, cisplatin, dacarbazine, chemotherapy the cell cycle), whereas dacarbazine caused $G_{1} / G_{0}$ cell cycle arrest, with the effects being improved by pre-treatment with vitamin D analogs. Treatment with cisplatin resulted in an initial increase in the level of reactive oxygen species (ROS). Dacarbazine caused transient stimulation of ROS levels and the mitochondrial membrane potential $\left(\Delta \psi_{\mathrm{m}}\right)$ (after 1 or $3 \mathrm{~h}$ of treatment, respectively), but the effect was not detectable following prolonged $(24 \mathrm{~h})$ incubation with the drug. Vitamin D exhibited modulatory effects on the cells treated with dacarbazine, decreasing the half maximal inhibitory concentration $\left(\mathrm{IC}_{50}\right.$ ) for the drug, stimulating $\mathrm{G}_{1} / \mathrm{G}_{0}$ arrest and causing a marked decrease in $\Delta \psi_{\mathrm{m}}$. Finally, cisplatin, dacarbazine and $1 \alpha, 25(\mathrm{OH})_{2} \mathrm{D} 3$ displayed modulatory effects on the expression of ROS and vitamin D-associated genes in the melanoma A375 cells. In conclusion, nanomolar concentrations of $1,25(\mathrm{OH})_{2} \mathrm{D}_{3}$ only had minor effects on the proliferation of melanoma cells treated with dacarbazine, decreasing the relative $\mathrm{IC}_{50}$ value. However, co-treatment with vitamin $\mathrm{D}$ analogs resulted in the modulation of cell cycle and ROS responses, and affected gene expression, suggesting possible crosstalk between the signaling pathways of vitamin D and the anticancer drugs used in this study.

\section{Introduction}

1 $\alpha, 25$-dihydroxyvitamin D3 $\left[1 \alpha, 25(\mathrm{OH})_{2} \mathrm{D} 3\right]$, or vitamin $\mathrm{D}$, is a lipid-soluble secosteroid produced by skin subjected to ultraviolet (UV)B radiation (1-3). Apart from its widely known beneficial role in the regulation of calcium homeostasis, vitamin $\mathrm{D}$ exerts pleiotropic effects, including regulation of the cell cycle, proliferation, differentiation and apoptosis (4-6). The active forms of vitamin $\mathrm{D}$ are important in the protection against DNA damage (7-9) and UVB-induced carcinogenesis in the skin (10-15). An inverse correlation between the concentration of vitamin D in serum and total cancer incidence and mortality has recently been described (16), implying, that vitamin D deficiency is a serious cancer risk factor $(13,17)$. An inverse correlation has also been demonstrated between the expression of the vitamin D receptor (VDR) and 25-hydroxyvitamin D3 
1- $\alpha$-hydroxylase (CYP27B1) with melanoma progression and disease outcome $(15,18,19)$. Therefore, active forms of vitamin $\mathrm{D}$ are now considered for therapeutic use in cancer prevention and treatment, supported by numerous epidemiological and preclinical studies (20-30). It should be emphasized that active forms of vitamin D used in combined therapy enhance the effectiveness of a number of anticancer drugs, including cisplatin (31,32), doxorubicin (33) and proton therapy (34). A previous study indicated that vitamin D analogs enhance the antiproliferative activity of cisplatin on keratinocytes (35). Furthermore, vitamin D and its analogs are currently being tested in clinical trials on various types of cancer, including melanoma $(36,37)$.

Melanoma, while accounting for only $4 \%$ of skin cancers, is linked to $80 \%$ of mortalities due to skin tumors, and therefore represents a significant public health problem $(30,38-42)$. This tumor is aggressive, but potentially curable by surgical excision if it is diagnosed at the early stages of development, including melanoma in situ or at the radial growth phase. However, with progression of the disease to the vertical growth phase, melanoma cells become resistant to the majority of forms of treatment, and acquire the ability to metastasize $(38,39,43)$. Furthermore, the incidence of melanoma has been rising in the Caucasian population worldwide over recent decades $(38,39)$. In 2017, melanoma was expected to be the fifth most common cancer in males and sixth most common in females in the USA (44). In recent years, major progress has been made with respect to our understanding of the molecular nature of melanoma and the interaction of melanoma cells with the immune system. Unfortunately, despite the marked expansion of advanced treatment options, primary or acquired resistance develops in patients, emphasizing the requirement for additional effort to develop effective melanoma therapy $(42,45)$.

The aim of the present study was to investigate the modulation of the anticancer properties of selected anti-melanoma chemotherapy agents by vitamin D and its nonor low-calcemic analogs 20S-hydroxyvitamin D3 [20(OH)D3], 21-hydroxypregnacalciferol [21(OH)pD] and calcipotriol (46-50), since the use of the hormonally active form of vitamin $\mathrm{D}$, $1 \alpha, 25(\mathrm{OH})_{2} \mathrm{D} 3$, at high doses is limited due to the risk of toxic effects, including hypercalcemia $(51,52)$. Notably, 20(OH)D3 is a natural product synthesized in the human body and detectable in human serum (53-55). It was hypothesized that vitamin D analogs would sensitize melanoma cells to classic chemotherapeutic drugs, based on a recent study documenting the association between vitamin $\mathrm{D}$ and oxidative stress in keratinocytes with a high proliferative potential, and the effect of vitamin D analogs on the sensitivity of these cells to cisplatin (35). Even though it is known that cisplatin induces DNA damage (56), it should be noted that the mechanism of action of cisplatin partially relies on the generation of reactive oxygen species (ROS) (57). Therefore the effects of dacarbazine, still used in melanoma therapy and also known to produce ROS in cells (58), and cisplatin, used in combination with vitamin D or its low calcemic analogs, were tested on the human malignant melanoma A375 cell line.

\section{Materials and methods}

Chemicals. $1,25(\mathrm{OH})_{2} \mathrm{D} 3$, hydrogen peroxide $(30 \%)$, cisplatin and dacarbazine were Sigma-Aldrich products (Merck KGaA,
Darmstadt, Germany). 21(OH)pD was synthesized according to Zmijewski et al (50) by ProChimia Surfaces Sp. z o. o. (Sopot, Poland). 20(OH)D3 was synthesized and purified as described previously (59). Calcipotriol was a gift from the Pharmaceutical Research Institute (Warsaw, Poland).

Cell culture. Human melanoma A375 cells (CRL-1619) were purchased from the American Type Culture Collection (Manassas, VA, USA). The cells were cultured in Dulbecco's modified Eagle's medium (DMEM) supplemented with 10\% fetal bovine serum (FBS) (both Sigma-Aldrich; Merck KGaA) and $1 \%$ penicillin/streptomycin in an incubator with $5 \% \mathrm{CO}_{2}$ at $37^{\circ} \mathrm{C}$. DMEM medium supplemented with $2 \%$ charcoal-stripped FBS was used for all experimental procedures where the effects of vitamin $\mathrm{D}$ derivatives were examined.

Proliferation assay. The sulphorhodamine B (SRB) assay was performed as previously described (35). Briefly, the human melanoma A375 cells were seeded in 96-well plates (7,000 cells per well), cultured overnight and then treated with serial dilutions of the compounds (vitamin D, $10^{-12}-10^{-6} \mathrm{M}$; hydrogen peroxide, 0.004-0.250 mM; cisplatin, 0.19-300 $\mu \mathrm{M}$; and dacarbazine, $0.15-10 \mu \mathrm{M}$ ) being tested for an additional 24 or 48 h. Following cell fixation with $10 \%$ trichloroacetic acid for $1 \mathrm{~h}$ at $4^{\circ} \mathrm{C}$, the plates were washed 5 times with distilled water and air-dried. Staining solution comprising of $0.4 \%$ SRB (Sigma-Aldrich; Merck KGaA) in acetic acid was added to each well for $15 \mathrm{~min}$, followed by washing with $1 \%$ acetic acid. The SRB dye was solubilized using a solution of $10 \mathrm{mM}$ buffered Tris Base ( $\mathrm{pH} 10.5)$ and the absorbance was measured at $570 \mathrm{~nm}$ using an Epoch $^{\mathrm{TM}}$ microplate spectrophotometer (BioTek Instruments, Inc., Winooski, VT, USA). The relative $\mathrm{IC}_{50}$ value was calculated as the concentration at which half the maximum inhibition was observed, i.e., the mid-point between no inhibition and the maximum observed decrease in proliferation $(60,61)$.

Cell cycle analysis. The cell cycle was analyzed by quantification of DNA content using flow cytometry. Trypsinized cells and cells from culture medium were fixed in $70 \%$ ethanol for 24-48 $\mathrm{h}$ at $4^{\circ} \mathrm{C}$, treated with ribonuclease in order to remove any contaminating RNA, and the DNA was stained with propidium iodide (PI; Sigma-Aldrich; Merck KGaA) for $30 \mathrm{~min}$ at $37^{\circ} \mathrm{C}$. The fluorescence of the PI-stained cells was measured by flow cytometry (excitation, $536 \mathrm{~nm}$; emission, 617 nm; FACSCalibur ${ }^{\mathrm{TM}}$; Becton, Dickinson and Company, Franklin, Lakes, NJ, USA). The results were analyzed using the CellQuest ${ }^{\mathrm{TM}}$ Pro Software version 6.0 (Becton, Dickinson and Company) and expressed as a percentage of cells with DNA content corresponding to apoptotic/necrotic cells $\left(\mathrm{subG}_{1}\right.$ fraction) or cells in $G_{1}, S$ and $G_{2} / M$ phases of the cycle.

Measurement of changes in the mitochondrial membrane potential $\left(\Delta \psi_{m}\right)$. The detection of changes in the inner electrochemical $\Delta \psi_{\mathrm{m}}$ in living cells was performed as described previously (35), using the cationic, lipophilic JC-1 dye (Thermo Fisher Scientific, Inc., Waltham, MA, USA). Carbonyl cyanide 3-chlorophenylhydrazone (CCCP; Sigma-Aldrich; Merck $\mathrm{KGaA}$ ), a mitochondrial potential disrupter, was used as a control. The melanoma A375 cells were pre-treated with 
Table I. Primer sequences.

\begin{tabular}{|c|c|c|}
\hline Gene & Forward primer $\left(3^{\prime}-5^{\prime}\right)$ & Reverse primer $\left(3^{\prime}-5^{\prime}\right)$ \\
\hline RPL37A & TTCTGATGGCGGACTTTACC & CACTTGCTCTTTCTGTGGCA \\
\hline SOD1 & CCACACCTTCACTGGTCCAT & CTAGCGAGTTATGGCGACG \\
\hline SOD2 & TAGGGCTGAGGTTTGTCCAG & CACCGAGGAGAAGTACCAGG \\
\hline$C A T$ & ACGGGGCCCTACTGTAATAA & AGATGCAGCACTGGAAGGAG \\
\hline$V D R$ & CCAGTTCGTGTGAATGATGG & GTCGTCCATGGTGAAGGA \\
\hline PDIA3 & CTCCGACGTGCTAGAACTCA & CAGGTGTTAGTGTTGGCAGT \\
\hline$C Y P 2 R 1$ & AGAGACCCAGAAGTGTTCCAT & GTCTTTCAGCACAGATGAGGTA \\
\hline СYР3А4 & AAGGCACCACCCACCTATGATACT & TACTTTGGGTCACGGTGAAGAGCA \\
\hline$C Y P 27 B 1$ & TGTTTGCATTTGCTCAGA & CCGGGAGAGCTCATACAG \\
\hline CYP24A1 & GCAGCCTAGTGCAGATTT & ATTCACCCAGAACTGTTG \\
\hline CYP11A1 & TGGGTCGCCTATCACCAGTAT & CCACCCGGTCTTTCTTCCA \\
\hline
\end{tabular}

RPL37A, ribosomal protein L37a; SOD1, superoxide dismutase 1; SOD2, superoxide dismutase 2; CAT, catalase; VDR, vitamin D receptor; PDIA3, protein disulfide isomerase A3; CYP2R1, vitamin D 25-hydroxylase; CYP3A4, cytochrome P450 3A4; CYP27B1, 25-hydroxyvitamin D3 1- $\alpha$-hydroxylase; CYP24A1, vitamin D 24-hydroxylase; CYP11A1 cholesterol side-chain cleavage enzyme.

secosteroids at a concentration of $100 \mathrm{nM}$ and then exposed to 2.4 and $12 \mu \mathrm{M}$ cisplatin or 2.0 and $10 \mu \mathrm{M}$ dacarbazine for an additional $3 \mathrm{~h}$, or to $75 \mathrm{nM}$ hydrogen peroxide for 1-3 h. Following the treatment with the selected compounds, the cells were harvested and suspended in $1 \mathrm{ml}$ PBS at room temperature. CCCP solution in dimethylsulfoxide (DMSO) was added to the positive control tube only ( $2 \mu \mathrm{M}$ final concentration) and the cells incubated at $37^{\circ} \mathrm{C}$ for $5 \mathrm{~min}$. JC- 1 solution $(2 \mu \mathrm{M}$ in DMSO) was added to all tubes and the cells were incubated at $37^{\circ} \mathrm{C}$ for $15 \mathrm{~min}$, then centrifuged at $1,000 \mathrm{x} \mathrm{g}$ for $10 \mathrm{~min}$ at room temperature, and resuspended in $500 \mu \mathrm{lPBS}$. The samples were kept on ice until they were analyzed on the FACSCalibur flow cytometer using the CellQuest Pro analysis software.

Detection of intracellular ROS production. The intracellular production of ROS was measured using $\mathrm{H}_{2}$ DCFDA (Thermo Fisher Scientific, Inc.). Cells were incubated with $100 \mathrm{nM}$ $1,25(\mathrm{OH})_{2} \mathrm{D} 3$ for $24 \mathrm{~h}$ followed by exposure to $24 \mu \mathrm{M}$ cisplatin or $6 \mu \mathrm{M}$ dacarbazine for 1 or $24 \mathrm{~h}$. $\mathrm{H}_{2}$ DCFDA was added to a final concentration of $10 \mu \mathrm{M} 30 \mathrm{~min}$ before the end of the incubation. The cells were washed and suspended in cold PBS. The samples were kept on ice until they were analyzed using the FACSCalibur flow cytometer using CellQuest Pro analysis software.

Measurement of $m R N A$ levels. The relative mRNA levels of particular genes were determined by a reverse transcription-quantitative polymerase chain reaction (qPCR) assay. Total RNA was isolated using the Total RNA Mini kit (A\&A Biotechnology, Gdynia, Poland), according to the manufacturer's instructions. The concentration and quality of RNA samples were determined using the Epoch spectrophotometer. A total of $1 \mu \mathrm{g}$ RNA was used for reverse transcription using the RevertAid ${ }^{\mathrm{TM}}$ First Strand cDNA Synthesis kit (Thermo Fisher Scientific, Inc.) by incubating at $42^{\circ} \mathrm{C}$ for $1 \mathrm{~h}$. The qPCR reaction comprised $1 \mu \mathrm{l}$ cDNA and $150 \mathrm{nM}$ of each primer (Table I), and was performed using the
SensiFAST ${ }^{\mathrm{Tm}}$ SYBR No-ROX kit (Bioline Reagents Limited, London, UK) in a total volume of $20 \mu \mathrm{l}$ on the StepOnePlus Real-Time PCR System (Thermo Fisher Scientific, Inc.). The thermocycling conditions were as follows: Initial denaturation at $95^{\circ} \mathrm{C}$ for $2 \mathrm{~min}$, followed by 40 cycles of $95^{\circ} \mathrm{C}$ for $5 \mathrm{sec}, 55-63^{\circ} \mathrm{C}$ for $10 \mathrm{sec}, 72^{\circ} \mathrm{C}$ for $15 \mathrm{sec}$ and $79^{\circ} \mathrm{C}$ for $10 \mathrm{sec}$. The melting curve analysis of the PCR products was performed following the qPCR reaction and consisted of $95^{\circ} \mathrm{C}$ for $15 \mathrm{sec}, 60^{\circ} \mathrm{C}$ for $1 \mathrm{~min}$ and $95^{\circ} \mathrm{C}$ for $15 \mathrm{sec}$. The reactions were run in duplicate and the resulting data were averaged prior to analysis with the StepOnePlus version 2.2.2. software (Thermo Fisher Scientific, Inc.). The RPL37 gene was used as a control to normalize the values by the $2^{-\Delta \Delta \mathrm{Cq}}$ quantification method (62).

Statistical analysis. Statistical analysis was performed using Microsoft Excel 2007 (Microsoft Corporation, Redmond, WA, USA) or GraphPad Prism version 6.03 (GraphPad Software, Inc., La Jolla, CA, USA). The data were subjected to Student's t-test for the comparison of two groups, one-way analysis of variance followed by Dunnett's or Tukey's multiple comparison post hoc tests. The data are expressed as the mean \pm standard deviation $(n=3-6)$. Differences were considered statistically significant when $\mathrm{P}<0.05$.

\section{Results}

Vitamin D analogs modulate the cytotoxic effects of hydrogen peroxide in human malignant melanoma A375 cells. In agreement with previous studies $(35,49,50,63,64)$ vitamin D analogs $1,25(\mathrm{OH})_{2} \mathrm{D} 3,20(\mathrm{OH}) \mathrm{D} 3,21(\mathrm{OH}) \mathrm{pD}$ and calcipotriol, effectively inhibited the proliferation of human melanoma A375 cells, as demonstrated by the SRB assay (Fig. 1A-D). A decrease of $\leq 20 \%$ in cell proliferation was observed, significant at the highest tested concentration of vitamin D analogs $\left(10^{-6} \mathrm{M}\right)$. The relative $\mathrm{IC}_{50}$ values ranged from $5.3 \mathrm{nM}$ for $20(\mathrm{OH}) \mathrm{D} 3$ to $\sim 0.274 \mathrm{nM}$ for $1,25(\mathrm{OH})_{2} \mathrm{D} 3$ and $0.038 \mathrm{nM}$ for calcipotriol (Fig. 1A-D). 
A

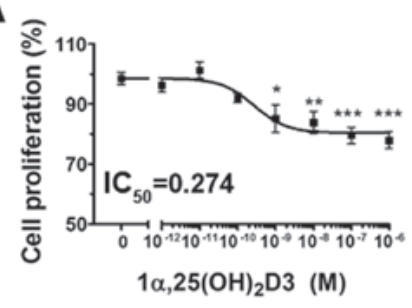

C

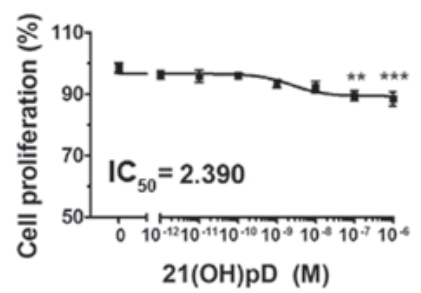

E

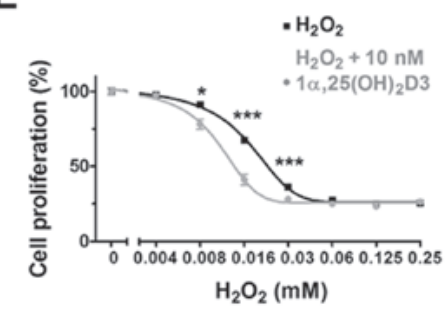

G

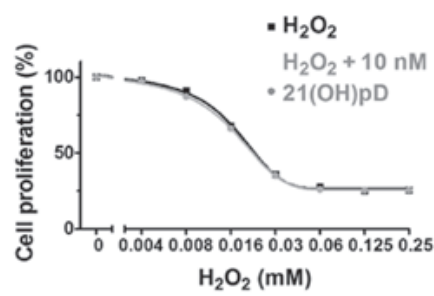

B

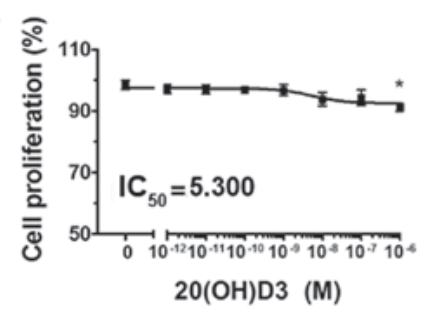

D

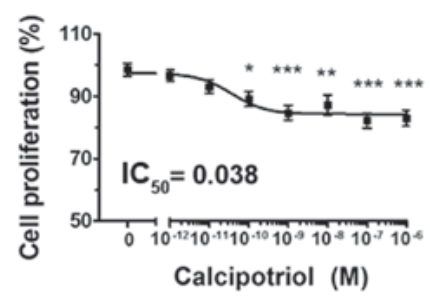

$\mathbf{F}$

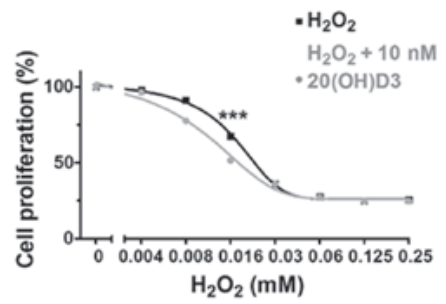

$\mathrm{H}$

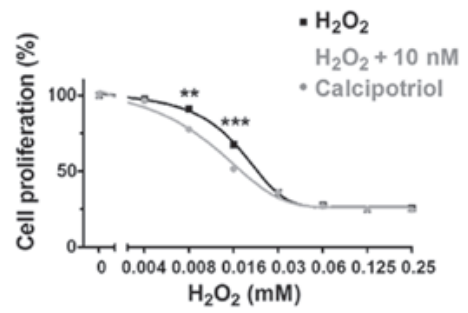

I

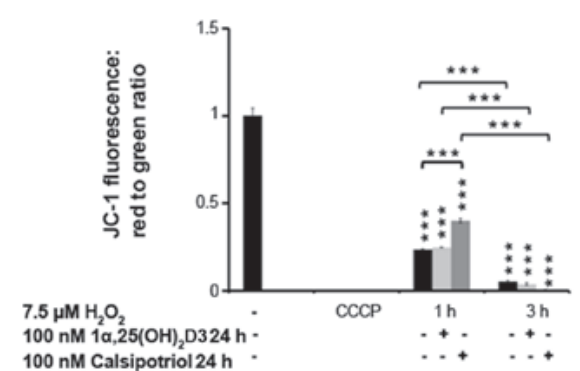

Figure 1. The effect of vitamin D derivatives on the proliferation of human melanoma A375 cells treated with $\mathrm{H}_{2} \mathrm{O}_{2}$. The cells were treated with serial dilutions $\left(10^{-12}-10^{-6} \mathrm{M}\right)$ of $(\mathrm{A}) 1,25(\mathrm{OH})_{2} \mathrm{D} 3$, (B) $20(\mathrm{OH}) \mathrm{D} 3$, (C) $21(\mathrm{OH}) \mathrm{pD}$ or (D) calcipotriol. ${ }^{*} \mathrm{P}<0.05,{ }^{* * *} \mathrm{P}<0.005$ and ${ }^{* * *} \mathrm{P}<0.0005$ versus control using one-way analysis of variance. The cells were treated with serial dilutions of $\mathrm{H}_{2} \mathrm{O}_{2}(0.0039-0.25 \mathrm{mM})$ alone or in combination with $(\mathrm{E}) 10 \mathrm{nM} 1,25(\mathrm{OH})_{2} \mathrm{D} 3,(\mathrm{~F}) 20(\mathrm{OH}) \mathrm{D} 3$, (G) $21(\mathrm{OH}) \mathrm{pD}$ or $(\mathrm{H})$ calcipotriol for $24 \mathrm{~h}$. The results presented are representative of three experiments $(\mathrm{n}=6) .{ }^{*} \mathrm{P}<0.05,{ }^{* *} \mathrm{P}<0.01$ and ${ }^{* * *} \mathrm{P}<0.001$ between the two treatments at each $\mathrm{H}_{2} \mathrm{O}_{2}$ concentration, using one-way analysis of variance followed by Tukey's multiple comparison test. The same control data is plotted in each graph. In order to investigate the effect of secosteroid pre-treatment on mitochondrial transmembrane potential, human melanoma A375 cells were

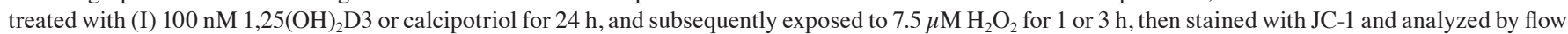
cytometry. The data are presented as mean \pm standard deviation of 3 independent experiments. ${ }^{* * * *} \mathrm{P}<0.001$ versus untreated control or between the two groups indicated by the bracket using one-way analysis of variance followed by Tukey's multiple comparison test. The positive control was exposed to CCCP for 5 min prior to staining with JC-1. IC50, half maximal inhibitory concentration; $1 \alpha, 25(\mathrm{OH})_{2} \mathrm{D} 3,1 \alpha, 25$-dihydroxyvitamin D3; 20(OH)D3, 20S-hydroxyvitamin D3; 21(OH)pD, 21-hydroxypregnacalciferol; $\mathrm{H}_{2} \mathrm{O}_{2}$, hydrogen peroxide; CCCP, carbonyl cyanide 3-chlorophenylhydrazone.

The effects of vitamin D derivatives on the sensitivity of A375 cells to ROS were also tested. Hydrogen peroxide, an oxidative stress-generating compound, inhibited the proliferation of the cells with a relative $\mathrm{IC}_{50}$ of $17 \mu \mathrm{M}$
(Fig. 1E-H). Simultaneous treatment with hydrogen peroxide and $1 \alpha, 25(\mathrm{OH})_{2} \mathrm{D} 3,20(\mathrm{OH}) \mathrm{D} 3$ or calcipotriol at a concentration of $10 \mathrm{nM}$ (Fig. 1E, F and $\mathrm{H}$ ) for $24 \mathrm{~h}$ resulted in a further decrease in the proliferation of the melanoma cells. 
Table II. Summary of the relative $\mathrm{IC}_{50}$ values for inhibition of proliferation of human melanoma $\mathrm{A} 375$ cells by $\mathrm{H}_{2} \mathrm{O}_{2}$ $(0.004-0.250 \mathrm{mM})$, cisplatin $(0.19-300 \mu \mathrm{M})$ or dacarbazine $(0.15-10 \mu \mathrm{M})$ in the presence or absence of the tested secosteroids.

\begin{tabular}{lccccc}
\hline & & \multicolumn{3}{c}{${\text { Relative } \mathrm{IC}_{50}}$} \\
\cline { 3 - 6 } $\begin{array}{l}\text { Incubation } \\
\text { time, } \mathrm{h}\end{array}$ & $\begin{array}{c}\text { Tested } \\
\text { compound }\end{array}$ & Monotreatment & $\begin{array}{c}+10 \mathrm{nM} \\
1 \alpha, 25(\mathrm{OH})_{2} \mathrm{D} 3\end{array}$ & $\begin{array}{c}+10 \mathrm{nM} \\
20(\mathrm{OH}) \mathrm{D} 3\end{array}$ & $\begin{array}{c}+10 \mathrm{nM} \\
21(\mathrm{OH}) \mathrm{pD}\end{array}$ \\
\hline 24 & $\mathrm{H}_{2} \mathrm{O}_{2}$ & $0.017 \pm 0.07$ & $0.011 \pm 0.001$ & $0.013 \pm 0.0006$ & $0.017 \pm 0.002$ \\
24 & Cisplatin & $4.81 \pm 2.2$ & $11.61 \pm 0.98^{\mathrm{a}}$ & $14.08 \pm 3.29^{\mathrm{b}}$ & $9.37 \pm 1.64$ \\
48 & Cisplatin & $2.57 \pm 0.19$ & $1.97 \pm 0.22$ & $3.47 \pm 1.04$ & $3.71 \pm 1.90$ \\
48 & Dacarbazine & $1.07 \pm 0.31$ & $0.45 \pm 0.35^{\mathrm{a}}$ & $1.17 \pm 0.40$ & $1.04 \pm 0.36$ \\
\hline
\end{tabular}

Data are presented as the mean \pm standard deviation of three independent experiments ( $n=6$ each). The data were subjected to analysis of variance followed by Tukey's multiple comparison test. ${ }^{a} \mathrm{P}<0.05$ and ${ }^{\mathrm{b}} \mathrm{P}<0.001$ vs. monotreatment. $\mathrm{IC}_{50}$, half maximal inhibitory concentration; $\mathrm{H}_{2} \mathrm{O}_{2}$, hydrogen peroxide; $1 \alpha, 25(\mathrm{OH})_{2} \mathrm{D} 3,1 \alpha, 25$-dihydroxyvitamin $\mathrm{D} 3 ; 20(\mathrm{OH}) \mathrm{D} 3,20 \mathrm{~S}$-hydroxyvitamin $\mathrm{D} 3 ; 21(\mathrm{OH}) \mathrm{pD}$, 21-hydroxypregnacalciferol .

\section{A}

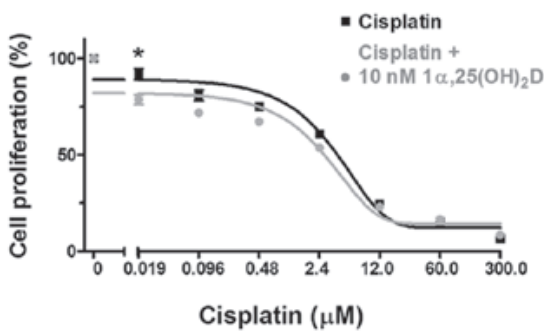

C

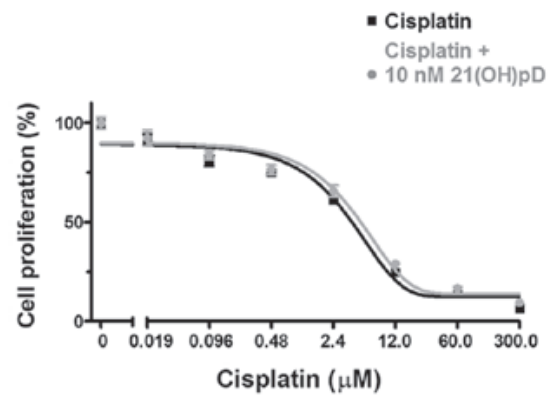

B

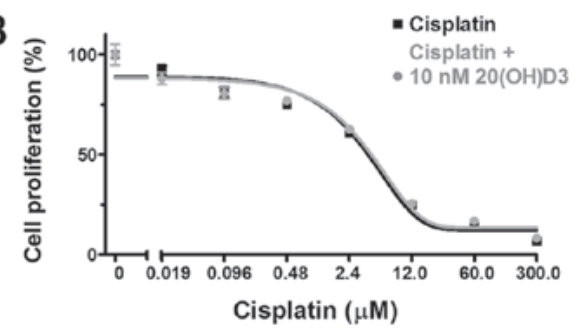

D
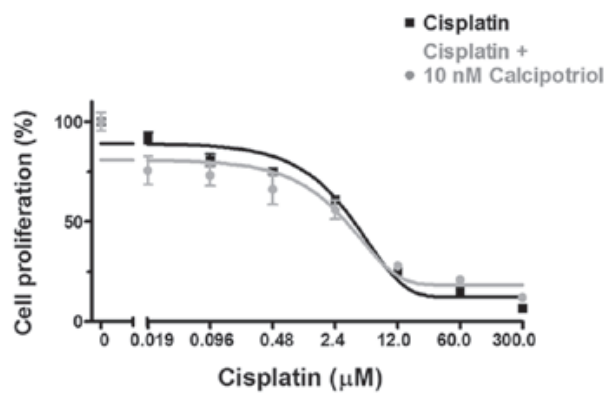

Figure 2. The effect of vitamin D derivatives on the proliferation of human melanoma A375 cells that were treated with cisplatin. Melanoma A375 cells were treated with serial dilutions of cisplatin $(0.019-300 \mu \mathrm{M})$ in combination with $10 \mathrm{nM}(\mathrm{A}) 1 \alpha, 25(\mathrm{OH})_{2} \mathrm{D} 3,(\mathrm{~B}) 20(\mathrm{OH}) \mathrm{D} 3,(\mathrm{C}) 21(\mathrm{OH}) \mathrm{pD}$ or $(\mathrm{D})$ calcipotriol for $48 \mathrm{~h}$. The results are representative of three experiments $(\mathrm{n}=6)$. The same control data is plotted in each graph. $\mathrm{P}<0.05$ between the two treatments at each cisplatin concentration, using one-way analysis of variance followed by Tukey's multiple comparison test. $1 \alpha, 25(\mathrm{OH}){ }_{2} \mathrm{D} 3,1 \alpha, 25-\mathrm{dihydroxyvitamin} \mathrm{D} 3$; 20(OH)D3, 20S-hydroxyvitamin D3; 21(OH)pD, 21-hydroxypregnacalciferol.

The effect was more pronounced for $1 \alpha, 25(\mathrm{OH})_{2} \mathrm{D} 3$ (Fig. 1E) and calcipotriol (Fig. 1H), however we did not observe any significant decrease between the calculated $\mathrm{IC}_{50}$ values (Table II). It has been suggested that altered mitochondrial activity may be a signature of certain melanoma cells (65). In the present study, changes in $\Delta \psi_{\mathrm{m}}$ were monitored using the JC-1 dual-emission potential-sensitive probe, by flow cytometry. The results revealed that the pre-incubation of the A375 cells with calcipotriol, but not $1 \alpha, 25(\mathrm{OH})_{2} \mathrm{D} 3$, for $24 \mathrm{~h}$ modulated the effect of hydrogen peroxide on the $\Delta \psi_{\mathrm{m}}$ (Fig. 1I). Notably, the pre-treatment with calcipotriol resulted in a protective effect on $\Delta \psi_{\mathrm{m}}$ in melanoma cells treated with hydrogen peroxide for $1 \mathrm{~h}$ (Fig. 1I). Prolonged exposure to hydrogen peroxide $(3 \mathrm{~h})$ in combination with pre-treatment of melanoma cells with either $1,25(\mathrm{OH})_{2} \mathrm{D} 3$ or calcipotriol triggered a decrease in $\Delta \psi_{\mathrm{m}}$ (Fig. 1I), although the observed differences were not significant.
Vitamin D analogs modulate the cytotoxic effects of cisplatin and dacarbazine on human malignant melanoma A375 cells. It is well established that oxidative stress and the resulting cell damage is one of the mechanisms of cell death induced by anticancer drugs. Thus, based on the aforementioned results with hydrogen peroxide (Fig. 1E-I), the effect of the treatment of A375 human melanoma cells with $1 \alpha, 25(\mathrm{OH})_{2} \mathrm{D} 3,20(\mathrm{OH})$ D3, $21(\mathrm{OH}) \mathrm{pD}$ or calcipotriol, on the ability of cisplatin or dacarbazine to inhibit proliferation, was investigated. These two drugs are widely used in melanoma treatment and their activity, at least partially, relies on ROS generation $(35,57,58,66)$. The anti-melanoma effects of cisplatin (Fig. 2A-D) or dacarbazine (Fig. 3A-D) alone or with $10 \mathrm{nM} 1 \alpha, 25(\mathrm{OH})_{2} \mathrm{D} 3,20(\mathrm{OH}) \mathrm{D} 3$, $21(\mathrm{OH}) \mathrm{pD}$ or calcipotriol were investigated in A375 cells using the SRB assay. Simultaneous treatment with vitamin D analogs and cisplatin for $24 \mathrm{~h}$ resulted in an unexpected increase in the cisplatin relative $\mathrm{IC}_{50}$, suggesting protective effects of the 
A

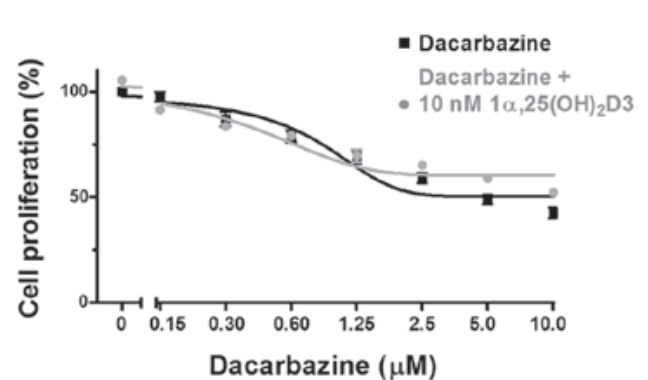

C

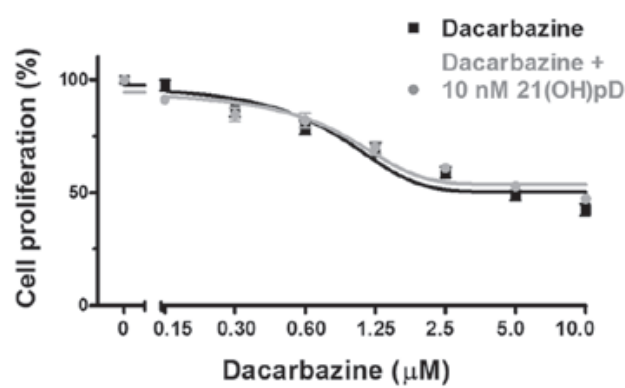

B

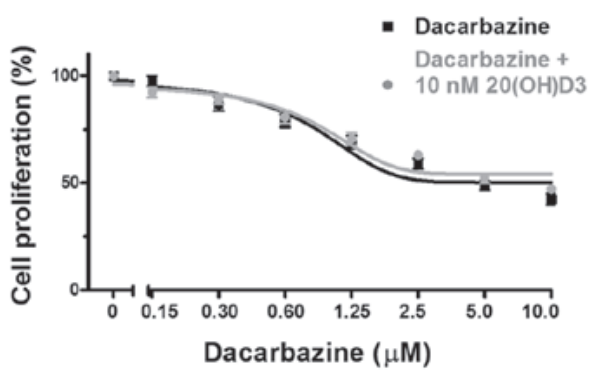

D

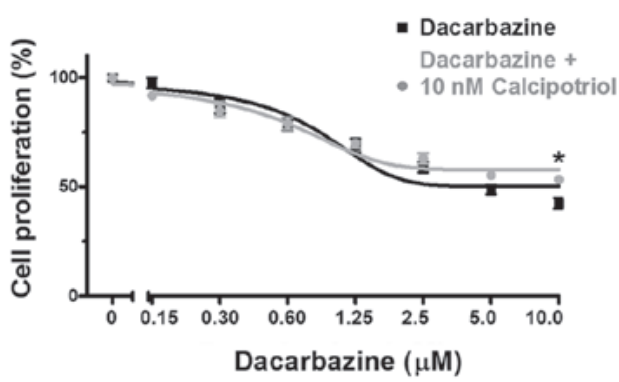

Figure 3. The effect of vitamin D derivatives on the proliferation of human melanoma A375 cells that were treated with dacarbazine. melanoma A375 cells were treated with serial dilutions of dacarbazine $(0.15-10 \mu \mathrm{M})$ in combination with $10 \mathrm{nM}(\mathrm{A}) 1 \alpha, 25(\mathrm{OH})_{2} \mathrm{D} 3,(\mathrm{~B}) 20(\mathrm{OH}) \mathrm{D} 3,(\mathrm{C}) 21(\mathrm{OH}) \mathrm{pD}$ or $(\mathrm{D})$ calcipotriol for $48 \mathrm{~h}$. The results are representative of three experiments $(\mathrm{n}=6)$. The same control data is included in all graphs. ${ }^{*} \mathrm{P}<0.05$ between the two treatments at each dacarbazine concentration, using one-way analysis of variance followed by Tukey's multiple comparison test. $1 \alpha, 25(\mathrm{OH})_{2} \mathrm{D} 3$, $1 \alpha, 25-\mathrm{dihydroxy}$ itamin $\mathrm{D} 3$; 20(OH)D3, 20S-hydroxyvitamin D3; 21(OH)pD, 21-hydroxypregnacalciferol.

secosteroids (Table II). However, during prolonged incubation with cisplatin $(48 \mathrm{~h})$, the addition of $1,25(\mathrm{OH})_{2} \mathrm{D} 3$, but not $20(\mathrm{OH}) \mathrm{D} 3,21(\mathrm{OH}) \mathrm{pD}$ or calcipotriol, resulted in a decreasing trend in the relative $\mathrm{IC}_{50}$ in comparison to cisplatin alone (Fig. 2; Table II), however the observed differences were not significant.

Dacarbazine inhibited the proliferation of human melanoma A375 cells during a $48 \mathrm{~h}$ incubation with a relative $\mathrm{IC}_{50}$ of $1.07 \mu \mathrm{M}$ (Table II). The results from the combined treatment with the vitamin $\mathrm{D}$ analogs revealed that $1 \alpha, 25(\mathrm{OH})_{2} \mathrm{D} 3$, but not $20(\mathrm{OH}) \mathrm{D} 3,21(\mathrm{OH}) \mathrm{pD}$ or calcipotriol, decreased the relative $\mathrm{IC}_{50}$ observed with dacarbazine alone by 2.3-fold (Table II).

Pre-treatment of human malignant melanoma A375 cells with vitamin $D$ derivatives alters the distribution of the cells in the cell cycle phases following treatment with dacarbazine, but not cisplatin. To investigate the mechanism of proliferation inhibition of melanoma A375 cell by the combination of vitamin D analogs and the tested drugs, changes in the distribution of the cells in the cell cycle phases were investigated by flow cytometry. The cells were pre-treated with the vitamin D analogs for $24 \mathrm{~h}$ and then incubated with cisplatin or dacarbazine for an additional 24 or $48 \mathrm{~h}$. The initial experiments revealed no significant effects of pre-treatment of melanoma cells for $24 \mathrm{~h}$ with $10 \mathrm{nM}$ secosteroids in combination with additional incubation with cisplatin for $24 \mathrm{~h}$ on the cell cycle distribution (data not shown). Since the results of the aforementioned SRB tests (Fig. 1A-D) demonstrated a plateau in the inhibition of cell proliferation at 10 and $100 \mathrm{nM}$ concentrations, and taking into consideration that vitamin $\mathrm{D}$ is widely used at higher concentrations (100-1,000 $\mathrm{nM}$ ) in in vitro studies (67-69), the concentration of vitamin D analogs was raised to $100 \mathrm{nM}$ for the present assay. Additionally, the time of incubation with cisplatin or dacarbazine was increased to $48 \mathrm{~h}$, similar to the conditions used during proliferation tests, and their concentrations were increased to 24 and $6 \mu \mathrm{M}$, respectively, to maximize the observed effect.

The treatment of melanoma A375 cells with $24 \mu \mathrm{M}$ cisplatin alone for $48 \mathrm{~h}$ resulted in an increase in the number of $\mathrm{SubG}_{1}$ cells $(\mathrm{P}<0.001)$, indicating induction of apoptosis with a concomitant decrease in the number of cells in the $\mathrm{G}_{0} / \mathrm{G}_{1}(\mathrm{P}<0.001), \mathrm{S}(\mathrm{P}<0.001)$ and $\mathrm{G}_{2} / \mathrm{M}(\mathrm{P}<0.001)$ phases (Fig. 4A-D). No impact of the vitamin D pre-treatment was observed on the distribution of cisplatin-treated melanoma cells in the cell cycle. The effect of pre-treatment of melanoma A375 cells with vitamin D analogs prior to incubation with dacarbazine was also tested (Fig. 4E-H). The treatment with $6 \mu \mathrm{M}$ dacarbazine alone for $48 \mathrm{~h}$ resulted in an increase in the fraction of cells in $G_{0} / G_{1}$ compared with untreated cells $(\mathrm{P}<0.01)$, with a minor effect on the $\mathrm{SubG}_{1}$ fraction $(\mathrm{P}<0.001)$ in comparison with cells treated with cisplatin alone $(<10$ vs. $>60 \%$ of all cells analyzed at $\mathrm{SubG}_{1}$ following treatment with dacarbazine or cisplatin, respectively; $\mathrm{P}<0.001$ cisplatin versus untreated cells; $\mathrm{P}<0.001$ dacarbazine versus untreated cells; Fig. 4A and E). In addition, $24 \mathrm{~h}$ pre-treatment with $100 \mathrm{nM} 1 \alpha, 25(\mathrm{OH})_{2} \mathrm{D} 3$ or calcipotriol prior to dacarbazine treatment resulted in an increase in the percentage of cells in the $G_{0} / G_{1}$ phase compared with that observed with dacarbazine alone $(\mathrm{P}<0.001$; Fig. $4 \mathrm{E}$ and $\mathrm{H})$. The effect was accompanied by a decrease in the percentage of cells in the $\mathrm{G}_{2} / \mathrm{M}$ phase for $1 \alpha, 25(\mathrm{OH})_{2} \mathrm{D} 3(\mathrm{P}<0.05$; Fig. $4 \mathrm{E})$, and in $\mathrm{S}$ and $\mathrm{G}_{2} / \mathrm{M}$ phases for calcipotriol $(\mathrm{P}<0.001$ and $\mathrm{P}<0.05$, respectively; Fig. $4 \mathrm{H})$.

Pre-treatment with vitamin $D$ derivatives changes the $\Delta \psi_{m}$ in human melanoma A375 cells and alters the cisplatin- or 
A
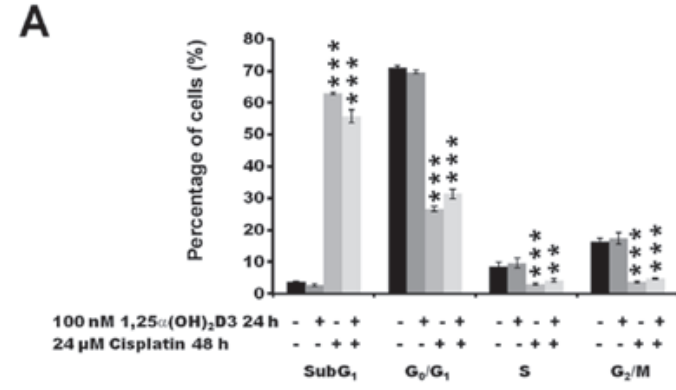

C $100 \mathrm{nM} \mathrm{1,25} \mathrm{a}(\mathrm{OH})_{2} \mathrm{D}$

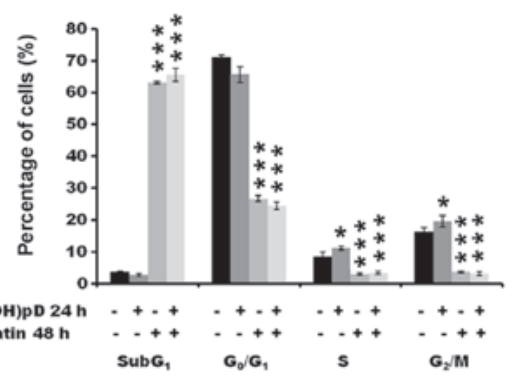

E $24 \mu \mathrm{M}$ Cisplat

Sube,

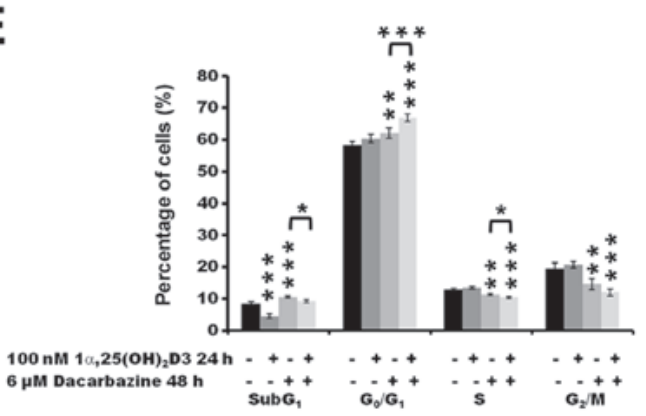

G

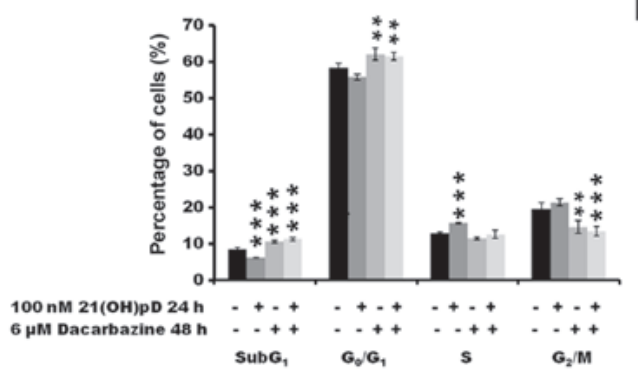

B
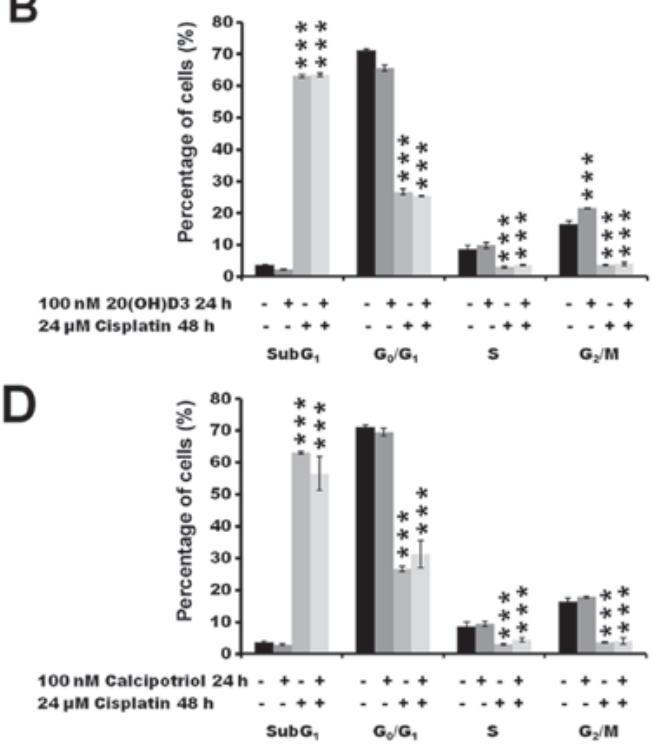

$\mathbf{F}$

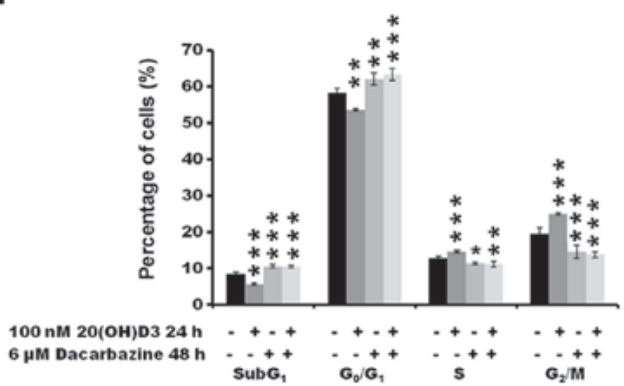

$\mathrm{H}$

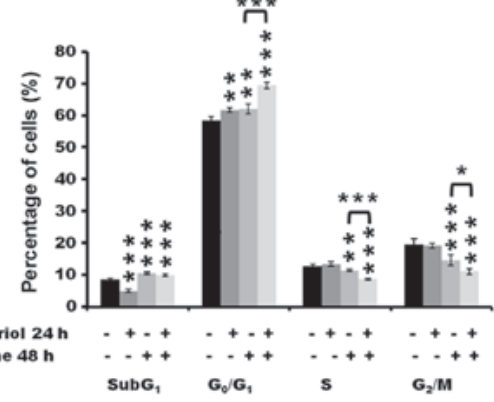

Figure 4. The effect of secosteroids and cisplatin or dacarbazine on the distribution of human melanoma A375 cells through the cell cycle. Cells that were treated with $24 \mu \mathrm{M}$ cisplatin for $48 \mathrm{~h}$ had been pre-treated with (A) $100 \mathrm{nM} 1 \alpha, 25(\mathrm{OH})_{2} \mathrm{D} 3$, (B) 20(OH)D3, (C) 21(OH)pD or (D) calcipotriol for 24 h. Similarly, cells that were treated with $6 \mu \mathrm{M}$ dacarbazine $48 \mathrm{~h}$ had been pre-treated with (E) $100 \mathrm{nM} 1 \alpha, 25(\mathrm{OH})_{2} \mathrm{D} 3,(\mathrm{~F}) 20(\mathrm{OH}) \mathrm{D} 3,(\mathrm{G}) 21(\mathrm{OH}) \mathrm{pD}$ or $(\mathrm{H})$ calcipotriol for $24 \mathrm{~h}$. The cells were harvested, stained with propidium iodide and analyzed by flow cytometry. The data are presented as the mean \pm standard deviation $(\mathrm{n}=3) .{ }^{*} \mathrm{P}<0.05,{ }^{* *} \mathrm{P}<0.01$ and ${ }^{* * * *} \mathrm{P}<0.001$, calculated using one-way analysis of variance followed by Tukey's multiple comparison test versus untreated control or between the two groups indicated by the bracket. SubG1, apoptotic/necrotic cells; G1, growth; S, DNA synthesis; G2/M, preparation for mitosis/mitosis; $1 \alpha, 25(\mathrm{OH})_{2} \mathrm{D} 3,1 \alpha, 25$-dihydroxyvitamin $\mathrm{D} 3 ; 20(\mathrm{OH}) \mathrm{D} 3,20 \mathrm{~S}$-hydroxyvitamin $\mathrm{D} 3$; 21(OH)pD, 21 -hydroxypregnacalciferol.

dacarbazine-induced production of ROS. The effects of the anti-cancer drugs on the $\Delta \psi_{\mathrm{m}}$ of the melanoma A375 cells were analyzed by measuring JC-1 fluorescence by flow cytometry (Figs. 5 and 6). Treatment with cisplatin alone for $3 \mathrm{~h}$ did not influence the $\Delta \psi_{\mathrm{m}}$, at either of the two concentrations tested (2.4 and $12 \mu \mathrm{M}$; Fig. 5A-D). A 24 h pre-treatment with $21(\mathrm{OH})$ $\mathrm{pD}$ (Fig. 5C) or calcipotriol (Fig. 5D) resulted in a decrease in $\Delta \psi_{\mathrm{m}}$ following treatment with cisplatin, compared to the cisplatin effect observed without pre-treatment. Notably, pre-treatment of the melanoma cells with $20(\mathrm{OH}) \mathrm{D} 3$ resulted in an increase in $\Delta \psi_{\mathrm{m}}$ (Fig. 5B) following exposure to $2.4 \mu \mathrm{M}$ cisplatin $(\mathrm{P}<0.001)$. However, this effect was not observed at higher concentration of the drug, or without the drug treatment.
A $3 \mathrm{~h}$ treatment with $2.0 \mu \mathrm{M}$ dacarbazine alone led to an increase in the $\Delta \psi_{\mathrm{m}}$ of melanoma A375 cells $(\mathrm{P}<0.001)$ but this was not the case at the higher concentration (10 $\mu \mathrm{M}$ ) (Fig. 6A-D). The $24 \mathrm{~h}$ pre-treatment of the cells with $1 \alpha, 25(\mathrm{OH})_{2} \mathrm{D} 3$ (Fig. 6A), 20(OH)D3 (Fig. 6B) or calcipotriol (Fig. 6D) resulted in a decrease in $\Delta \psi_{\mathrm{m}}$ following exposure to $2.0 \mu \mathrm{M}$ dacarbazine $\left(\mathrm{P}<0.01\right.$ for $1 \alpha, 25(\mathrm{OH})_{2} \mathrm{D} 3$ and $\mathrm{P}<0.001$ for $20(\mathrm{OH}) \mathrm{D} 3$ and calcipotriol versus dacarbazine alone). In the case of $21(\mathrm{OH}) \mathrm{pD}$ (Fig. $6 \mathrm{C}$ ), the effect was not statistically significant. In contrast, at the higher concentration of dacarbazine $(10 \mu \mathrm{M})$, the pre-treatment of the cells with $1,25(\mathrm{OH})_{2} \mathrm{D} 3,20(\mathrm{OH}) \mathrm{D} 3$ or calcipotriol resulted in an increase in $\Delta \psi_{\mathrm{m}}(\mathrm{P}<0.05, \mathrm{P}<0.001$ and $\mathrm{P}<0.01$, respectively, versus 
A

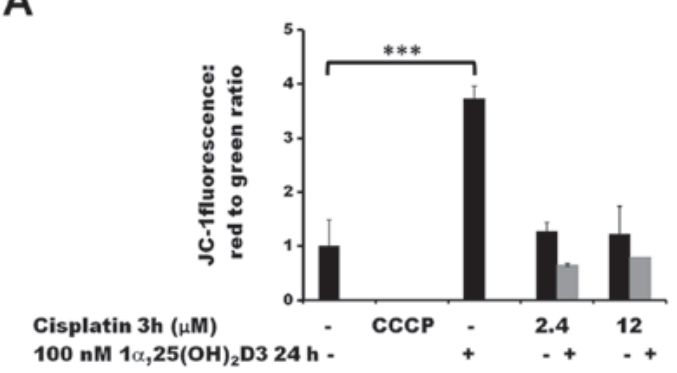

C

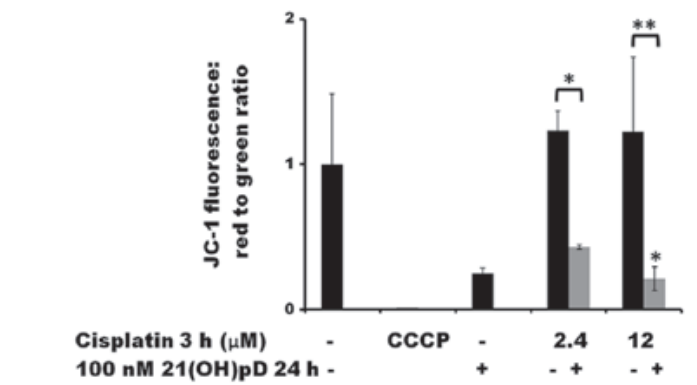

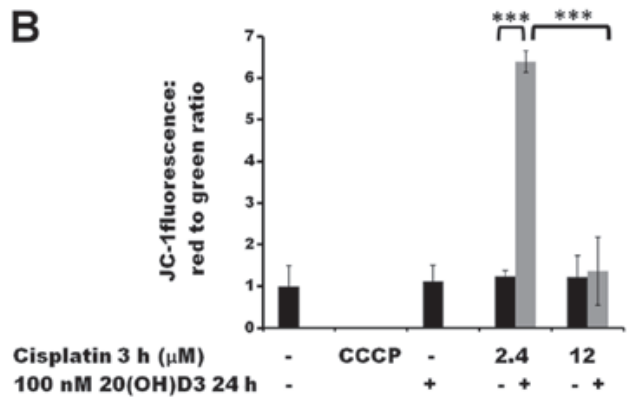

D

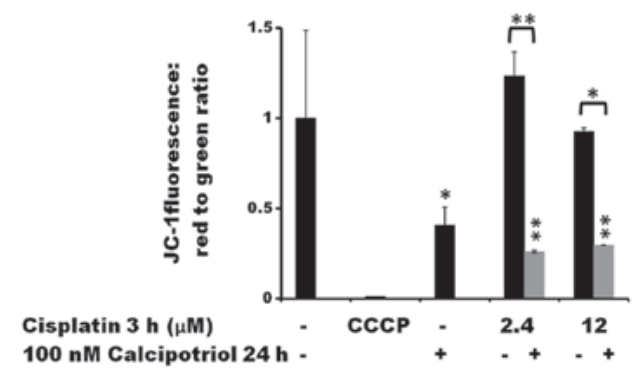

E

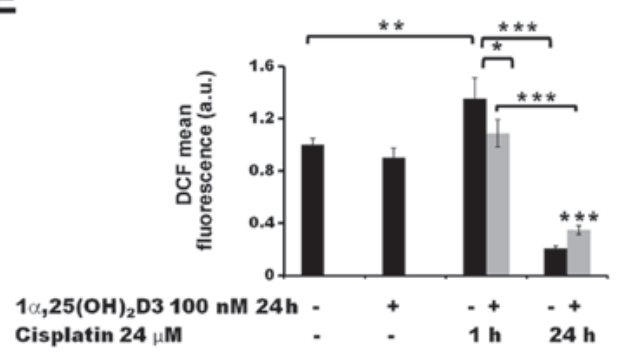

Figure 5. The effect of pre-treatment of human melanoma A375 cells with vitamin D derivatives on the cisplatin-induced changes in the mitochondrial membrane potential and ROS levels. A375 cells were treated with (A) $100 \mathrm{nM} 1 \alpha, 25(\mathrm{OH})_{2} \mathrm{D} 3$, (B) 20(OH)D3, (C) $21(\mathrm{OH}) \mathrm{pD}$ or (D) calcipotriol for $24 \mathrm{~h}$, and subsequently exposed to 2.4 or $12 \mu \mathrm{M}$ cisplatin for $3 \mathrm{~h}$. The cells were stained with JC-1 and analyzed by flow cytometry. The positive control was exposed to CCCP for 5 min prior to staining with JC-1. (E) The effect of $1 \alpha, 25(\mathrm{OH})_{2} \mathrm{D} 3$ on ROS levels. The cells were treated with $100 \mathrm{nM} 1,25(\mathrm{OH})_{2} \mathrm{D} 3 \mathrm{for} 24 \mathrm{~h}$ and subsequently exposed to $24 \mu \mathrm{M}$ cisplatin for 1 or $24 \mathrm{~h}$. The cells were stained with $\mathrm{H}_{2}$ DCFDA and analyzed by flow cytometry. The data are presented as the mean \pm standard deviation $(\mathrm{n}=3)$. ${ }^{*} \mathrm{P}<0.05 ;{ }^{* *} \mathrm{P}<0.01$; and ${ }^{* * *} \mathrm{P}<0.001$, calculated using one way analysis of variance followed by Tukey's multiple comparison test between the two groups indicated by the bracket or compared with the untreated control. $1 \alpha, 25(\mathrm{OH})_{2} \mathrm{D} 3,1 \alpha, 25-\mathrm{dihydroxyvitamin} \mathrm{D} 3$; $20(\mathrm{OH}) \mathrm{D} 3$, 20S-hydroxyvitamin D3; 21(OH)pD, 21-hydroxypregnacalciferol; CCCP, carbonyl cyanide 3-chlorophenylhydrazone; ROS, reactive oxygen species.

$10 \mu \mathrm{M}$ dacarbazine alone). No significant difference was observed in the case of pre-treatment with $21(\mathrm{OH}) \mathrm{pD}$.

A pre-treatment of malignant melanoma A375 cells with $100 \mathrm{nM} 1,25(\mathrm{OH})_{2} \mathrm{D} 3$ for $24 \mathrm{~h}$ did not influence the production of ROS in comparison with untreated cells, as determined by the $\mathrm{H}_{2}$ DCFDA assay (Figs. $5 \mathrm{E}$ and $6 \mathrm{E}$ ). However, this pre-treatment affected the ROS production following treatment with either cisplatin (Fig. 5E) or dacarbazine (Fig. 6E). The observed effect was time-dependent. Exposure of the cells to cisplatin or dacarbazine alone for $1 \mathrm{~h}$, without vitamin D pre-treatment, led to a significant increase in the ROS levels $(\mathrm{P}<0.01$ for cisplatin and $\mathrm{P}<0.001$ for dacarbazine; Figs. $5 \mathrm{E}$ and $6 \mathrm{E}$, respectively). However, $24 \mathrm{~h}$ pre-treatment of melanoma cells with $1 \alpha, 25(\mathrm{OH})_{2} \mathrm{D} 3$ decreased the effect that the $1 \mathrm{~h}$ cisplatin or dacarbazine treatment had on the ROS levels $(\mathrm{P}<0.05$ versus no pre-treatment; Fig. 5E). In contrast, prolonged exposure $(24 \mathrm{~h})$ to cisplatin or dacarbazine alone tended towards a decrease in the ROS levels in the melanoma cells, whereas the $1 \alpha, 25(\mathrm{OH})_{2} \mathrm{D} 3$ pre-treatment alleviated the effect of the $24 \mathrm{~h}$ cisplatin or dacarbazine treatment on the ROS levels, although the observed differences were not significant.

Modulation of the expression of selected genes by cisplatin or dacarbazine in the presence or absence of $1 \alpha, 25(\mathrm{OH})_{2} \mathrm{D} 3$. In order to verify the aforementioned changes in ROS generation and the $\Delta \psi_{\mathrm{m}}$, the impact of $1 \alpha, 25(\mathrm{OH})_{2} \mathrm{D} 3$ pre-treatment on the expression of the selected ROS-associated genes was tested in melanoma A375 cells treated with cisplatin or dacarbazine (Fig. 7). No significant effect was observed in the expression of superoxide dismutases 1 and 2 (SOD1 and SOD2) or catalase $(C A T)$ by $1 \alpha, 25(\mathrm{OH})_{2} \mathrm{D} 3$ under the experimental conditions used (Fig. 7A-C). Treatment of the cells with the anticancer drugs had a limited effect on the mRNA levels of the selected ROS-associated genes. A decrease in SOD2 gene expression was observed under the influence of cisplatin alone $(\mathrm{P}<0.05$ vs. no treatment control; Fig. 7B), as well as in SODI and $C A T$ gene expression following treatment with dacarbazine alone (both $\mathrm{P}<0.05$ vs. no treatment control; Fig. 7A and $\mathrm{C}$, respectively). Pre-treatment of the cells with $1 \alpha, 25(\mathrm{OH})_{2} \mathrm{D} 3$ 
A

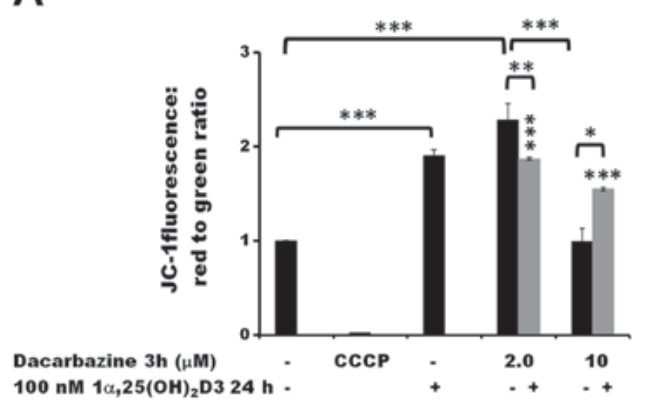

C

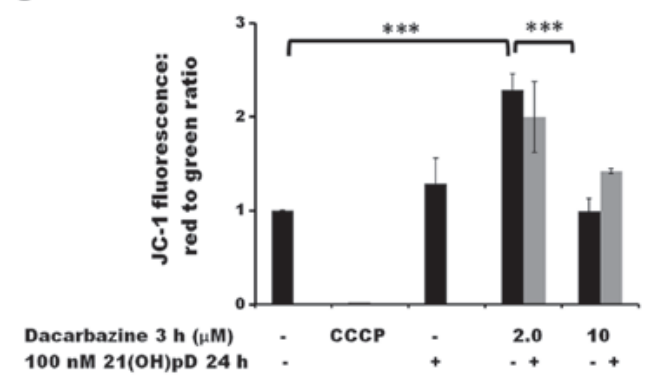

B

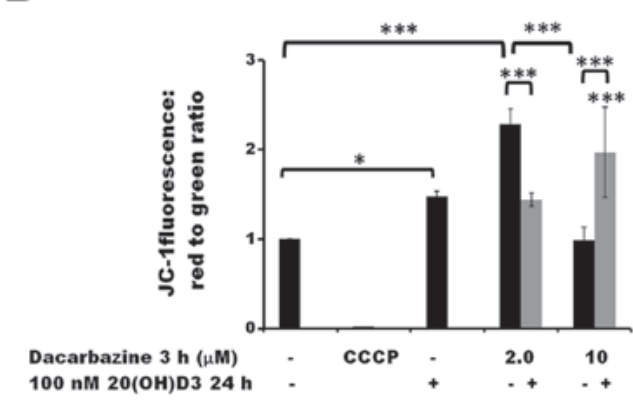

D

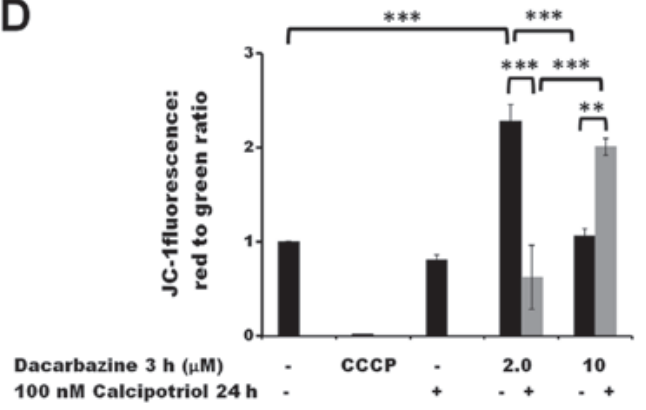

E

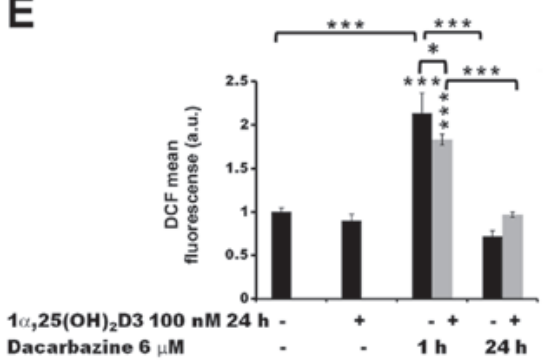

Figure 6. The effect of pre-treatment of human melanoma A375 cells with vitamin D derivatives on the dacarbazine-induced changes in the mitochondrial

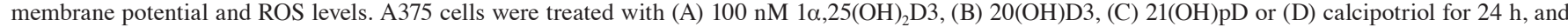
subsequently exposed to 2.0 or $10 \mu \mathrm{M}$ dacarbazine for $3 \mathrm{~h}$ The cells were stained with JC-1 and analyzed by flow cytometry. The positive control was exposed to CCCP for 5 min prior to staining with $\mathrm{JC}-1$. (E) The effect of $1 \alpha, 25(\mathrm{OH})_{2} \mathrm{D} 3$ on ROS levels. The cells were treated with $100 \mathrm{nM} 1,25(\mathrm{OH}){ }_{2} \mathrm{D} 3$ for $24 \mathrm{~h}$ and subsequently exposed to $6 \mu \mathrm{M}$ dacarbazine for 1 or $24 \mathrm{~h}$. The cells were stained with $\mathrm{H}_{2} \mathrm{DCFDA}$ and analyzed by flow cytometry. The data are presented as the mean \pm standard deviation $(\mathrm{n}=3) .{ }^{*} \mathrm{P}<0.05,{ }^{* *} \mathrm{P}<0.01$ and ${ }^{* * * *} \mathrm{P}<0.001$, calculated using one way analysis of variance followed by Tukey's multiple comparison test between the two groups indicated by the bracket or compared with the untreated control. $1 \alpha, 25(\mathrm{OH})_{2} \mathrm{D} 3,1 \alpha, 25-\mathrm{dihydroxy}$ itamin $\mathrm{D} 3$; $20(\mathrm{OH}) \mathrm{D} 3$, 20S-hydroxyvitamin D3; 21(OH)pD, 21-hydroxypregnacalciferol; CCCP, carbonyl cyanide 3-chlorophenylhydrazone; ROS, reactive oxygen species.

prior to incubation with dacarbazine resulted in an increase of $C A T$ mRNA compared with cells treated solely with dacarbazine $(\mathrm{P}<0.05$; Fig. $7 \mathrm{C})$.

Subsequently, the effect of cisplatin or dacarbazine on the expression of vitamin $\mathrm{D}$-associated genes, including ones encoding vitamin $\mathrm{D}$ receptors $V D R$ and protein disulfide-isomerase A3 (PDIA3), and vitamin D metabolizing hydroxylases that belong to the cytochrome P450 (CYP) family, CYP2R1, CYP3A4, CYP27B1, CYP24A1 and CYP11A1, was investigated in melanoma A375 cells, as well as the consequences of pre-treatment with $1 \alpha, 25(\mathrm{OH})_{2} \mathrm{D} 3$. The results revealed that $1 \alpha, 25(\mathrm{OH})_{2} \mathrm{D} 3$ and cisplatin, used alone, decreased VDR mRNA levels in the A375 cells $(\mathrm{P}<0.05$; Fig. 7D). The effect of dacarbazine was statistically significant only in the case of the $1 \alpha, 25(\mathrm{OH})_{2} \mathrm{D} 3$ pre-treatment $(\mathrm{P}<0.05$; Fig. 7D). In contrast, $1 \alpha, 25(\mathrm{OH})_{2} \mathrm{D} 3$ and cisplatin had no effect on PDIA3 mRNA levels (Fig. 7E), whereas dacarbazine alone led to a significant decrease $(\mathrm{P}<0.05)$. Notably, the effect of dacarbazine alone was reversed by the $1 \alpha, 25(\mathrm{OH})_{2} \mathrm{D} 3$ pre-treatment $(\mathrm{P}<0.05)$.
Although the transcription of $C Y P 2 R 1$ was not affected by $1 \alpha, 25(\mathrm{OH})_{2} \mathrm{D} 3$, cisplatin or dacarbazine alone, pre-treatment of the A375 cells with $1 \alpha, 25(\mathrm{OH})_{2} \mathrm{D} 3$ with subsequent exposure to dacarbazine resulted in an increase in its mRNA $(\mathrm{P}<0.05$; Fig. 7F) compared with that in the cells treated with dacarbazine alone. Stimulation of $C Y P 3 A 4$ expression was observed with all combinations of the drugs tested. The effect was further exacerbated by a $24 \mathrm{~h} 1 \alpha, 25(\mathrm{OH})_{2} \mathrm{D} 3$ pre-treatment (Fig. 7G). Treatment with $1 \alpha, 25(\mathrm{OH})_{2} \mathrm{D} 3$ or cisplatin alone or in combination had no statistically significant effect on the $C Y P 27 B 1$ mRNA levels (Fig. 7H). However, treatment with dacarbazine alone resulted in a decrease $(\mathrm{P}<0.001)$ and this effect was reversed by prior administration of $1 \alpha, 25(\mathrm{OH})_{2} \mathrm{D} 3(\mathrm{P}<0.01)$. As expected, pre-treatment of the cells with $1 \alpha, 25(\mathrm{OH})_{2} \mathrm{D} 3$ resulted in a strong stimulation of CYP24A1, which encodes the vitamin D deactivation enzyme, 24-hydroxylase (Fig. 7I). An increase in CYP24A1 mRNA levels was also observed for cisplatin or dacarbazine alone, although to a lesser extent [7- and 5-fold increase, respectively, versus a 1,700 -fold increase for $\left.1 \alpha, 25(\mathrm{OH})_{2} \mathrm{D} 3\right]$. Furthermore, 


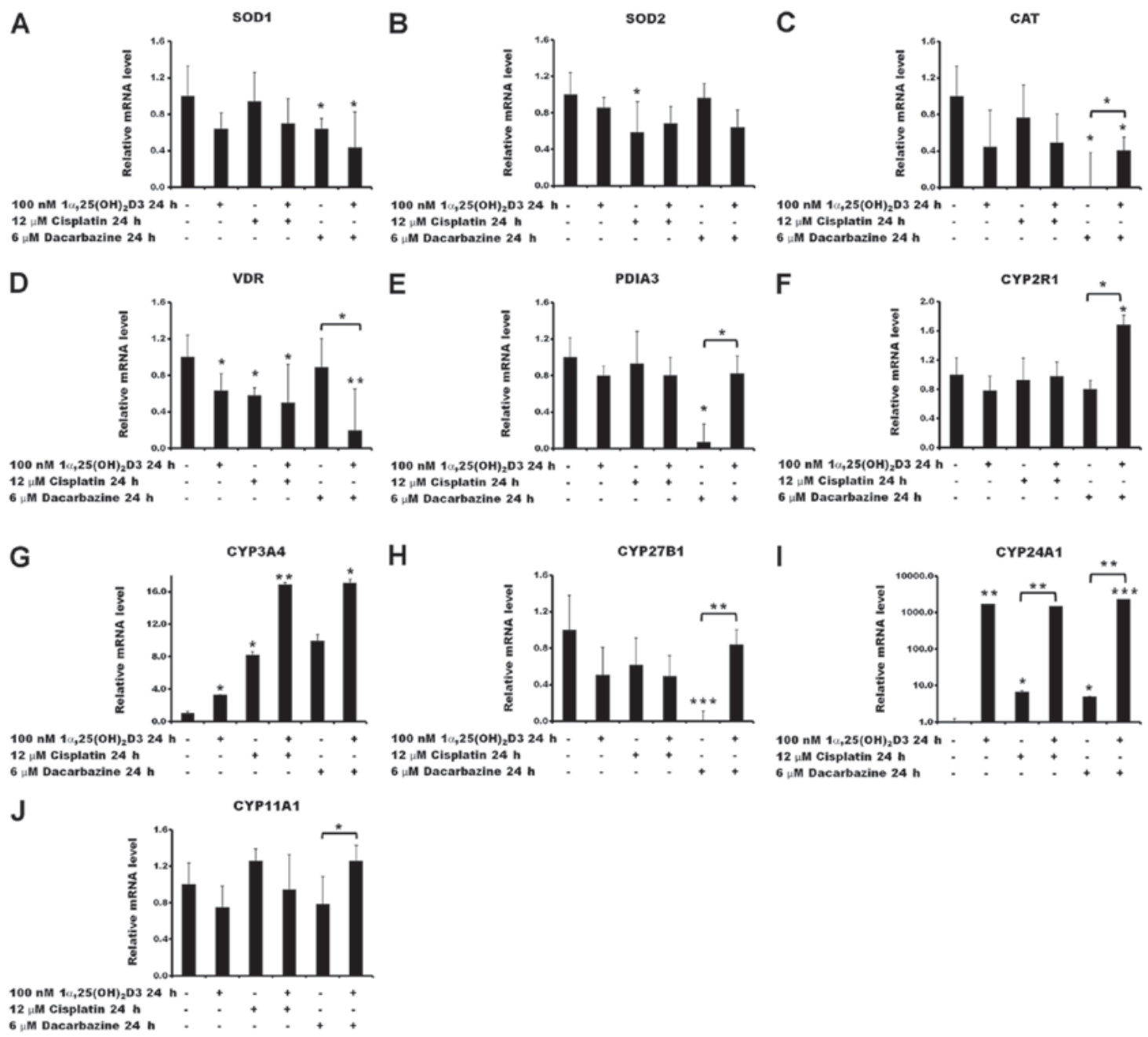

Figure 7. Relative mRNA quantification of reactive oxygen species- and vitamin D-associated genes. Effects of cisplatin or dacarbazine treatment on the mRNA levels of (A) SOD1, (B) SOD2, (C) CAT, (D) VDR, (E) PDIA3, (F) CYP2R1, (G) CYP3A4, (H) CYP27B1, (I) CYP24A1 and (J) CYP11A1 gene expression

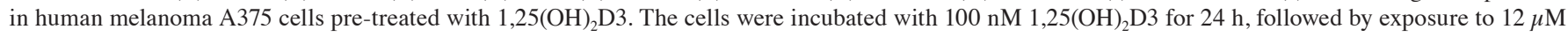
cisplatin or $6 \mu \mathrm{M}$ dacarbazine for an additional $24 \mathrm{~h}$. The mRNA levels were measured by reverse transcription-quantitative polymerase chain reactions The data are presented as the mean \pm standard deviation of 3 independent experiments carried out in duplicate. ${ }^{*} \mathrm{P}<0.05,{ }^{* * *} \mathrm{P}<0.01$ and ${ }^{* * * *} \mathrm{P}<0.001$, calculated using Student's t-test vs. untreated control or between the two groups indicated by the bracket. $1 \alpha, 25(\mathrm{OH})_{2} \mathrm{D} 3,1 \alpha, 25$-dihydroxyvitamin $\mathrm{D} 3$; SOD, superoxide dismutase; CAT, catalase; VDR, vitamin D receptor; PDIA3, protein disulfide-isomerase A3; CYP2R1, vitamin D 25-hydroxylase; CYP3A4, cytochrome P450 3A4; CYP27B1, 25-hydroxyvitamin D3 1- $\alpha$-hydroxylase; CYP24A1, vitamin D 24-hydroxylase; CYP11A1, cholesterol side-chain cleavage enzyme.

cisplatin or dacarbazine had no effect on the level of $C Y P 24 A 1$ mRNA following pre- treatment with $1 \alpha, 25(\mathrm{OH})_{2} \mathrm{D} 3$, compared with cells treated solely with $1 \alpha, 25(\mathrm{OH})_{2} \mathrm{D} 3$ (Fig. 7I). Treatment of the A375 cells with $1 \alpha, 25(\mathrm{OH})_{2} \mathrm{D} 3$, cisplatin or dacarbazine alone did not affect the transcription levels of the CYP11A1 gene (Fig. 7J). Finally, the pre-treatment with $1 \alpha, 25(\mathrm{OH})_{2} \mathrm{D} 3$ followed by treatment with dacarbazine resulted in a small, but significant, increase in the CYP11Al mRNA level ( $\mathrm{P}<0.05$ vs. dacarbazine alone).

\section{Discussion}

It is well established that $\mathrm{UV}$ radiation is a major skin carcinogen that serves an important role in melanomagenesis $(14,70,71)$. However, UVB is also indispensable for the production of vitamin D in the skin (1-3). Considering the antiproliferative and differentiation-promoting function of vitamin $\mathrm{D}$ and its analogs, it seemed advantageous to explore their efficacy as anticancer drugs and their potential for positive interactions with other antimelanoma drugs or therapeutic approaches (34). The effects of the active forms of vitamin D require VDR activation, which results in the modulation of the expression in $\sim 3,000$ target genes in humans (72), including those involved in DNA repair and the oxidative stress response (73). Vitamin D deficiency is considered to contribute to carcinogenesis, and notably, to poor prognosis due to multidrug resistance $(74,75)$. Recently published data suggest an inverse correlation between the vitamin D serum level and the relative risk of melanoma and non-melanoma skin cancer, as well as melanoma thickness at diagnosis $(30,75,76)$. Wyatt et al (77) also suggested that vitamin D deficiency at the time of melanoma diagnosis is not only associated with a higher Breslow thickness but also with a poorer prognosis. Ogbah et al (78) reported that even in patients living in the sunny Mediterranean area, $1 \alpha, 25(\mathrm{OH})_{2} \mathrm{D} 3$ levels were sub-optimal at the time of melanoma diagnosis. Patients with metastatic melanoma, who were initially vitamin D deficient, had significantly poorer outcomes in comparison to individuals who, being initially deficient, exhibited a 
$>20 \mathrm{ng} / \mathrm{ml}$ increase in their 25-hydroxyvitamin D3 [25(OH) D3] concentration during the therapy period (75). Vitamin D deficient patients with stage IV metastatic melanoma also had significantly poorer prognosis (75). Therefore, the administration of vitamin $\mathrm{D}$ is potentially beneficial in cancer therapy.

A previous study has revealed that melanoma A375 cells are $\geq 10$ times more sensitive to hydrogen peroxide than human immortalized HaCaT keratinocytes. The interaction between hydrogen peroxide, as a model oxidative stress inducer, and vitamin D analogs were investigated (35). First, as reported for HaCaT keratinocytes (35), the incubation of melanoma A375 cells with vitamin D analogs resulted in higher sensitivity of the cells to hydrogen peroxide treatment (Fig. 1). It should be emphasized that $\mathrm{HaCaT}$ keratinocytes represent a cellular model of epithelial cells, whereas melanocytes are derived from neural crest cells (79) and therefore represent a different cellular model. Hence, the present study focused on human malignant melanoma cells. Hydrogen peroxide treatment was used to investigate the association between ROS levels and vitamin $\mathrm{D}$ analogs, and subsequently the interaction between vitamin D analogs and anticancer drugs was explored.

Secondly, similar effects to those discussed above for hydrogen peroxide were observed for dacarbazine, but not cisplatin, following treatment with $1 \alpha, 25(\mathrm{OH})_{2} \mathrm{D} 3$, since sensitization of $1 \alpha, 25(\mathrm{OH})_{2} \mathrm{D} 3$-treated melanoma cells to this drugs was observed. Notably, the highest concentration of cisplatin $(300 \mu \mathrm{M})$ resulted in a decrease in cell proliferation as measured using the SRB assay, by $>90 \%$, whereas treatment with $10 \mu \mathrm{M}$ dacarbazine decreased proliferation by $50 \%$. Incubation of the melanoma A375 cells with $1 \alpha, 25(\mathrm{OH})_{2} \mathrm{D} 3$, $20(\mathrm{OH}) \mathrm{D} 3,21(\mathrm{OH}) \mathrm{pD}$ or calcipotriol for $24 \mathrm{~h}$ resulted in up to a $20 \%$ decrease in cell proliferation at the highest concentrations tested. This inhibitory effect of the vitamin D analogs, with the exception of $20(\mathrm{OH}) \mathrm{D} 3$, is consistent with previous studies $(80,81)$, however certain differences were noted in the relative $\mathrm{IC}_{50}$ values [i.e., $1 \alpha, 25(\mathrm{OH})_{2} \mathrm{D} 3$ relative $\mathrm{IC}_{50}, 0.274$ vs. $6.4 \mathrm{nM}$ reported by Wasiewicz et al (81)]. The variation among the relative $\mathrm{IC}_{50}$ values could be explained by variable experimental conditions, including a shorter incubation time with vitamin D analogs (24 vs. 48 h), as well as a lower FBS concentration in the medium. It is already known that vitamin $\mathrm{D}$ inhibits cell proliferation and promotes their differentiation $(80,82,83)$. Therefore, the inhibition of melanoma cell proliferation by vitamin $\mathrm{D}$ should not be considered as a direct cytotoxic effect, but rather reveals its antiproliferative potential.

Thirdly, it appears that these two drugs inhibit melanoma cell proliferation via distinct mechanisms $(58,66)$. It should be noted that even though cisplatin and dacarbazine function primarily based on the induction of DNA damage $(56,84)$, it is apparent that these drugs also lead to the generation of ROS inside treated cells $(57,58)$. The current study design was based on a $24 \mathrm{~h}$ pre-treatment with vitamin D analogs at a low concentration $(100 \mathrm{nM})$. This corresponds to the optimal level of $25(\mathrm{OH}) \mathrm{D} 3$ in the serum $(75-125 \mathrm{nM})(28)$, since, according to Timerman et al (75), vitamin D deficiency is associated with a poorer prognosis in metastatic melanoma. As demonstrated by the cell cycle analyses, induction of apoptosis (increase in $\mathrm{SubG}_{1}$ cell fraction) was observed for the cells treated with cisplatin, consistent with other studies $(85,86)$. On the other hand, the inhibition of melanoma cell proliferation by dacarbazine probably results from cell cycle arrest, as observed from an increase in the number of cells in the $G_{0} / G_{1}$ fraction $(\mathrm{P}<0.01)$ and decreases in the $\mathrm{S}$ and $\mathrm{G}_{2} / \mathrm{M}$ phases (both $\mathrm{P}<0.01$ ). As expected based on previous studies $(15,17,80,82,83)$, pre-treatment with active forms of vitamin $\mathrm{D}$ resulted in an increase in the number of cells in $\mathrm{G}_{0} / \mathrm{G}_{1}$, with this effect being observed in cells treated with dacarbazine, but not cisplatin. Notably, the two anticancer drugs exhibited similar effects on oxidative stress. Treatment of the melanoma cells with the two drugs resulted in an initial significant increase in oxidative stress (at $1 \mathrm{~h}$ ), whereas prolonged incubation $(24 \mathrm{~h})$ resulted in a downward trend of 2',7'-dichlorofluorescein fluorescence in cells treated with cisplatin or dacarbazine compared with the untreated control. The pre-incubation with vitamin D analogs, however, resulted in a drug-specific effect on $\Delta \psi_{\mathrm{m}}$. In the case of cisplatin, a significant decrease in $\Delta \psi_{\mathrm{m}}$ was only observed in cells pre-treated with vitamin $\mathrm{D}$ derivatives, $21(\mathrm{OH}) \mathrm{pD}$ and calcipotriol $(\mathrm{P}<0.05$ and $\mathrm{P}<0.01$, respectively). It has been reported that cisplatin-resistant lung cancer cells exhibit increased $\Delta \psi_{\mathrm{m}}$ in comparison with cisplatin-sensitive counterparts (87). Therefore, a decrease in $\Delta \psi_{\mathrm{m}}$ in cisplatin-treated cells elicited by vitamin D analogs possibly reflects their drug-sensitization potential. The effect of the incubation of melanoma cells with the secosteoids, with the exception of $21(\mathrm{OH}) \mathrm{pD}$, prior to treatment with dacarbazine was dose-dependent, with a decrease in $\Delta \psi \mathrm{m}$ in cells treated with a low concentration of the drug $(2 \mu \mathrm{M})$, and an increase at the high concentration $(10 \mu \mathrm{M})$.

The analyses of the expression levels of selected genes involved in the response to ROS or the modulation of vitamin $\mathrm{D}$ activity, revealed potential regulatory properties of dacarbazine. This drug resulted in significant inhibition of the expression of $C A T$, the alternative vitamin $\mathrm{D}$ binding protein encoded by $P D I A 3$, and $C Y P 27 B 1$, with these effects being reversed by pre-treatment with $1 \alpha, 25(\mathrm{OH})_{2} \mathrm{D} 3$. All the tested analogs efficiently induced the expression of $C Y P 3 A 4$, with the effect of cisplatin or dacarbazine treatment being enhanced by secosteroid pre-treatment. This observation indicates the induction of an anti-xenobiotic response in the melanoma A375 cells. Similar results for cisplatin and other anticancer compounds were reported in hepatocyte-derived HepG2 cells, in which chemotherapeutic agents activated cellular tumor antigen p53 protein to induce the expression of the main enzymes involved in the systemic clearance of these drugs (88). On the other hand, dacarbazine, a prodrug, requires activation by the cytochrome P450 (CYP450) enzyme family, to which the product of $C Y P 3 A 4$ belongs (89). Therefore, the observed induction of $C Y P 3 A 4$ expression may also suggest more efficient oxidation of dacarbazine to its active metabolite in melanoma cells pre-treated with vitamin D. Cells overexpressing another CYP450 family member, CYP450 2E1 (CYP2E1), were revealed to be more sensitive to cisplatin treatment with respect to cell viability and ROS production, compared with cells lacking CYP2E1 expression (90).

CYP24A1 is pivotal for vitamin D homeostasis, since it regulates the serum and tissue levels of $25(\mathrm{OH}) \mathrm{D} 3$ and $1 \alpha, 25(\mathrm{OH})_{2} \mathrm{D} 3$, being the major vitamin $\mathrm{D}$ inactivating enzyme (91). A strong induction of CYP24Al expression 
was observed with $100 \mathrm{nM} 1 \alpha, 25(\mathrm{OH})_{2} \mathrm{D} 3$ (Fig. 7I). This observation is consistent with previous reports for melanoma A375 cells (81) and HaCaT keratinocytes (35). Notably, an increase in CYP24A1 expression was also observed in cells treated with $12 \mu \mathrm{M}$ cisplatin or $6 \mu \mathrm{M}$ dacarbazine alone (Fig. 7I). A similar induction of CYP24AI expression by cisplatin has been observed in HepG2 cells in a p53-dependent manner (88). Furthermore, dacarbazine is a well known powerful alkylating agent that activates p53 (92). Therefore, the induction of CYP24A1 expression in A375 melanoma cells by this chemotherapeutic agent may involve a p53-dependent mechanism. However, this hypothesis requires further investigation.

Similarities and differences were noted in the phenotypic effects between $1 \alpha, 25(\mathrm{OH})_{2} \mathrm{D} 3$ and calcipotriol versus non-calcemic 20(OH)D3 and 21(OH)pD. These can be explained by the different receptors targeted by each of these molecules. Although the VDR is the primary target for $1 \alpha, 25(\mathrm{OH})_{2} \mathrm{D} 3$ and calcipotriol, $20(\mathrm{OH}) \mathrm{D} 3$ acts only as a biased agonist on the VDR and can act as a reverse agonist on retinoic acid orphan receptors (46,93-96), whereas its downstream metabolite, $20,23(\mathrm{OH})_{2} \mathrm{D} 3$, acts as an agonist on the aryl hydrocarbon receptor (97). In the case of $21(\mathrm{OH}) \mathrm{pD}$, its nuclear receptor remains to be identified, since it has low or no affinity for the VDR (98). Defining the precise mechanism of action for each secosteroid is a future goal.

In vitro studies require further validation by in vivo animal studies prior to the use of vitamin D in combination with cisplatin or dacarbazine in melanoma treatment. However, pre-clinical models of human melanoma, including cell line-transplantable mouse models, genetically engineered mouse models or immunodeficient mice with patient-derived xenografts (PDOX), do not reflect the true nature of the primary tumor, being controversial in their ability to translate the effectiveness of immunotherapeutic strategies in clinical trials $(99,100)$. Nevertheless, animal models, including PDOX, are the next logical step to discovering novel targets for more efficient combinatorial therapy and approaches to overcome emerging resistance of melanoma cells to any form of treatment (101-103).

Despite not observing pronounced enhancement of anti-melanoma activity by the tested chemotherapeutics under the described experimental conditions, the results of the present study have demonstrated that vitamin D analogs modulate the response of melanoma cells to dacarbazine. In conclusion, low- and non-calcemic vitamin D analogs may serve as beneficial adjuvant agents in chemotherapy, particularly in patients suffering from vitamin D deficiency.

\section{Acknowledgments}

Not applicable.

\section{Funding}

This study was supported by grant no. MN 01-0250/08/280 from the Medical University of Gdansk (Gdansk, Poland) to AP, and in part by NIH grants (nos. 1R01AR073004-01A1 and 1RO1AR071189-01A1) and a VA merit grant (no. 1I01BX004293-01A1) to ATS.

\section{Availability of data and materials}

The datasets used and/or analyzed during the current study are available from the corresponding author on reasonable request.

\section{Authors' contributions}

MAZ and AP conceived and designed and supervised the study; AP, JW and AR performed the experiments; RCT provided vitamin D analogs; MAZ, AP, JW, RCT and ATS analyzed the data; AP, MAZ, RCT and ATS wrote the manuscript. All authors have read and approved the final manuscript.

\section{Ethics approval and consent to participate}

Not applicable.

\section{Patient consent for publication}

Not applicable.

\section{Competing interests}

The authors declare that they have no competing interests.

\section{References}

1. Piotrowska A, Wierzbicka J and Żmijewski MA: Vitamin D in the skin physiology and pathology. Acta Biochim Pol 63: 17-29, 2016.

2. Holick MF: Vitamin D: Evolutionary, physiological and health perspectives. Curr Drug Targets 12: 4-18, 2011.

3. Bikle DD: Vitamin D and the skin: Physiology and pathophysiology. Rev Endocr Metab Disord 13: 3-19, 2012.

4. Samuel S and Sitrin MD: Vitamin D's role in cell proliferation and differentiation. Nutr Rev 66 (Suppl 2): S116-S124, 2008.

5. Bikle DD: Vitamin D regulated keratinocyte differentiation. J Cell Biochem 92: 436-444, 2004.

6. Kubis AM and Piwowar A: The new insight on the regulatory role of the vitamin D3 in metabolic pathways characteristic for cancerogenesis and neurodegenerative diseases. Ageing Res Rev 24 (Pt B): 126-137, 2015.

7. Slominski AT, Janjetovic Z, Kim TK, Wasilewski P, Rosas S, Hanna S, Sayre RM, Dowdy JC, Li W and Tuckey RC: Novel non-calcemic secosteroids that are produced by human epidermal keratinocytes protect against solar radiation. J Steroid Biochem Mol Biol 148: 52-63, 2015.

8. Gordon-Thomson C, Gupta R, Tongkao-on W, Ryan A, Halliday GM and Mason RS: $1 \alpha, 25$ dihydroxyvitamin D3 enhances cellular defences against UV-induced oxidative and other forms of DNA damage in skin. Photochem Photobiol Sci 11: 1837-1847, 2012.

9. Fedirko V, Bostick RM, Long Q, Flanders WD, McCullough ML, Sidelnikov E, Daniel CR, Rutherford RE and Shaukat A: Effects of supplemental vitamin D and calcium on oxidative DNA damage marker in normal colorectal mucosa: A randomized clinical trial. Cancer Epidemiol Biomarkers Prev 19: 280-291, 2010.

10. Jiang YJ, Teichert AE, Fong F, Oda Y and Bikle DD: $1 \alpha, 25(\mathrm{OH}) 2$-dihydroxyvitamin $\mathrm{D} 3 / \mathrm{VDR}$ protects the skin from UVB-induced tumor formation by interacting with the $\beta$-catenin pathway. J Steroid Biochem Mol Biol 136: 229-232, 2013.

11. Dixon KM, Deo SS, Wong G, Slater M, Norman AW, Bishop JE, Posner GH, Ishizuka S, Halliday GM, Reeve VE, et al: Skin cancer prevention: A possible role of 1,25dihydroxyvitamin D3 and its analogs. J Steroid Biochem Mol Biol 97: 137-143, 2005.

12. Wong G, Gupta R, Dixon KM, Deo SS, Choong SM, Halliday GM, Bishop JE, Ishizuka S, Norman AW, Posner GH, et al: 1,25-Dihydroxyvitamin D and three low-calcemic analogs decrease UV-induced DNA damage via the rapid response pathway. J Steroid Biochem Mol Biol 89-90: 567-570, 2004. 
13. Bikle DD, Jiang Y, Nguyen T, Oda Y and Tu CL: Disruption of Vitamin D and Calcium Signaling in Keratinocytes Predisposes to Skin Cancer. Front Physiol 7: 296, 2016.

14. Holick MF: Sunlight, ultraviolet radiation, vitamin D and skin cancer: How much sunlight do we need? Adv Exp Med Biol 810 1-16, 2014.

15. Slominski AT, Brożyna AA, Skobowiat C, Zmijewski MA, Kim TK, Janjetovic Z, Oak AS, Jozwicki W, Jetten AM, Mason RS, et al: On the role of classical and novel forms of vitamin D in melanoma progression and management. J Steroid Biochem Mol Biol 177: 159-170, 2018.

16. Yin L, Ordóñez-Mena JM, Chen T, Schöttker B, Arndt V and Brenner H: Circulating 25-hydroxyvitamin D serum concentration and total cancer incidence and mortality: A systematic review and meta-analysis. Prev Med 57: 753-764, 2013.

17. Reichrath J, Zouboulis CC, Vogt T and Holick MF: Targeting the vitamin $\mathrm{D}$ endocrine system (VDES) for the management of inflammatory and malignant skin diseases: An historical view and outlook. Rev Endocr Metab Disord 17: 405-417, 2016.

18. Brożyna AA, Jóźwicki W, Janjetovic Z and Slominski AT: Expression of the vitamin D-activating enzyme 1 $\alpha$-hydroxylase (CYP27B1) decreases during melanoma progression. Hum Pathol 44: 374-387, 2013.

19. Brożyna AA, Jóźwicki W and Slominski AT: Decreased VDR expression in cutaneous melanomas as marker of tumor progression: New data and analyses. Anticancer Res 34: 2735-2743, 2014

20. Ma Y, Trump DL and Johnson CS: Vitamin D in combination cancer treatment. J Cancer 1: 101-107, 2010.

21. Krishnan AV, Swami S and Feldman D: Equivalent anticancer activities of dietary vitamin $\mathrm{D}$ and calcitriol in an animal model of breast cancer: Importance of mammary CYP27B1 for treatment and prevention. J Steroid Biochem Mol Biol 136: 289-295, 2013.

22. Morris HA: Vitamin D activities for health outcomes. Ann Lab Med 34: 181-186, 2014.

23. Mitchell D: The relationship between vitamin D and cancer. Clin J Oncol Nurs 15: 557-560, 2011.

24. Welsh J, Wietzke JA, Zinser GM, Byrne B, Smith K and Narvaez CJ: Vitamin D-3 receptor as a target for breast cancer prevention. J Nutr 133 (Suppl): 2425S-2433S, 2003.

25. Lamprecht SA and Lipkin M: Chemoprevention of colon cancer by calcium, vitamin D and folate: Molecular mechanisms. Nat Rev Cancer 3: 601-614, 2003.

26. Bolland MJ, Grey A, Gamble GD and Reid IR: Calcium and vitamin D supplements and health outcomes: A reanalysis of the Women's Health Initiative (WHI) limited-access data set. Am J Clin Nutr 94: 1144-1149, 2011.

27. Grant WB: 25-hydroxyvitamin D and breast cancer, colorectal cancer, and colorectal adenomas: Case-control versus nested case-control studies. Anticancer Res 35: 1153-1160, 2015.

28. Płudowski P, Karczmarewicz E, Bayer M, Carter G, Chlebna-Sokół D, Czech-Kowalska J, Dębski R, Decsi T, Dobrzańska A, Franek E, et al: Practical guidelines for the supplementation of vitamin D and the treatment of deficits in Central Europe - recommended vitamin D intakes in the general population and groups at risk of vitamin D deficiency. Endokrynol Pol 64: 319-327, 2013.

29. Skobowiat C, Oak AS, Kim TK, Yang CH, Pfeffer LM, Tuckey RC and Slominski AT: Noncalcemic 20-hydroxyvitamin D3 inhibits human melanoma growth in in vitro and in vivo models. Oncotarget 8: 9823-9834, 2017.

30. Slominski AT, Brożyna AA,Zmijewski MA, Jóźwicki W, Jetten AM, Mason RS, Tuckey RC and Elmets CA: Vitamin D signaling and melanoma: Role of vitamin $\mathrm{D}$ and its receptors in melanoma progression and management. Lab Invest 97: 706-724, 2017.

31. Ma Y, Yu WD, Trump DL and Johnson CS: 1,25D3 enhances antitumor activity of gemcitabine and cisplatin in human bladder cancer models. Cancer 116: 3294-3303, 2010.

32. Rassnick KM, Muindi JR, Johnson CS, Balkman CE, Ramnath N, $\mathrm{Yu}$ WD, Engler KL, Page RL and Trump DL: In vitro and in vivo evaluation of combined calcitriol and cisplatin in dogs with spontaneously occurring tumors. Cancer Chemother Pharmacol 62: 881-891, 2008

33. Wietrzyk J, Nevozhay D, Filip B, Milczarek M and Kutner A: The antitumor effect of lowered doses of cytostatics combined with new analogs of vitamin D in mice. Anticancer Res 27 (5A): 3387-3398, 2007.

34. Podgorska E, Drzal A, Matuszak Z, Swakon J, Slominski A, Elas M and Urbanska K: Calcitriol and Calcidiol Can Sensitize Melanoma Cells to Low(-)LET Proton Beam Irradiation. Int J Mol Sci 19: 19, 2018.
35. Piotrowska A, Wierzbicka J, Ślebioda T, Woźniak M, Tuckey RC, Slominski AT and Żmijewski MA: Vitamin D derivatives enhance cytotoxic effects of $\mathrm{H} 2 \mathrm{O} 2$ or cisplatin on human keratinocytes. Steroids 110: 49-61, 2016.

36. Saw RP, Armstrong BK, Mason RS, Morton RL, Shannon KF, Spillane AJ, Stretch JR and Thompson JF: Adjuvant therapy with high dose vitamin $\mathrm{D}$ following primary treatment of melanoma at high risk of recurrence: A placebo controlled randomised phase II trial (ANZMTG 02.09 Mel-D). BMC Cancer 14: 780, 2014.

37. Pettijohn E, Martone B, Rademaker A and Kuzel T: A phase I study of high-dose calcitriol in combination with temozolomide for patients with metastatic melanoma. J Pers Med 4: 448-458, 2014.

38. Batus M, Waheed S, Ruby C, Petersen L, Bines SD and Kaufman HL: Optimal management of metastatic melanoma: Current strategies and future directions. Am J Clin Dermatol 14: 179-194, 2013.

39. Shah DJ and Dronca RS: Latest advances in chemotherapeutic, targeted, and immune approaches in the treatment of metastatic melanoma. Mayo Clin Proc 89: 504-519, 2014.

40. Arnold M, de Vries E, Whiteman DC, Jemal A, Bray F, Parkin DM and Soerjomataram I: Global burden of cutaneous melanoma attributable to ultraviolet radiation in 2012. Int J Cancer 143: 1305-1314, 2018

41. Mattia G,Puglisi R, Ascione B,Malorni W, Carè A and Matarrese P: Cell death-based treatments of melanoma:conventional treatments and new therapeutic strategies. Cell Death Dis 9: 112, 2018.

42. Slominski AT and Carlson JA: Melanoma resistance: A bright future for academicians and a challenge for patient advocates. Mayo Clin Proc 89: 429-433, 2014.

43. Russo A, Ficili B, Candido S, Pezzino FM, Guarneri C, Biondi A, Travali S, McCubrey JA, Spandidos DA and Libra M: Emerging targeted therapies for melanoma treatment (Review). Int J Oncol 45: 516-524, 2014.

44. Siegel RL, Miller KD and Jemal A: Cancer Statistics, 2017. CA Cancer J Clin 67: 7-30, 2017.

45. Johnson DB, Pollack MH and Sosman JA: Emerging targeted therapies for melanoma. Expert Opin Emerg Drugs 21: 195-207, 2016.

46. Slominski AT, Kim TK, Li W, Yi AK, Postlethwaite A and Tuckey RC: The role of CYP11A1 in the production of vitamin D metabolites and their role in the regulation of epidermal functions. J Steroid Biochem Mol Biol 144 (Pt A): 28-39, 2014.

47. Slominski AT, Janjetovic Z, Fuller BE, Zmijewski MA, Tuckey RC, Nguyen MN, Sweatman T, Li W, Zjawiony J, Miller D, et al: Products of vitamin D3 or 7-dehydrocholesterol metabolism by cytochrome P450scc show anti-leukemia effects, having low or absent calcemic activity. PLoS One 5: e9907, 2010.

48. Wang J, Slominski A, Tuckey RC, Janjetovic Z, Kulkarni A, Chen J, Postlethwaite AE, Miller D and Li W: 20-hydroxyvitamin $\mathrm{D}_{3}$ inhibits proliferation of cancer cells with high efficacy while being non-toxic. Anticancer Res 32: 739-746, 2012

49. Wasiewicz T, Szyszka P, Cichorek M, Janjetovic Z, Tuckey RC, Slominski AT and Zmijewski MA: Antitumor effects of vitamin $\mathrm{d}$ analogs on hamster and mouse melanoma cell lines in relation to melanin pigmentation. Int J Mol Sci 16: 6645-6667, 2015.

50. Zmijewski MA, Li W, Chen J, Kim TK, Zjawiony JK, Sweatman TW, Miller DD and Slominski AT: Synthesis and photochemical transformation of 33,21-dihydroxypregna-5,7-die $\mathrm{n}$-20-one to novel secosteroids that show anti-melanoma activity. Steroids 76: 193-203, 2011.

51. Koul PA, Ahmad SH, Ahmad F, Jan RA, Shah SU and Khan UH: Vitamin d toxicity in adults: A case series from an area with endemic hypovitaminosis d. Oman Med J 26: 201-204, 2011.

52. Podgorska E, Sniegocka M, Mycinska M, Trybus W, Trybus E, Kopacz-Bednarska A, Wiechec O, Krzykawska-Serda M, Elas M, Krol T, et al: Acute hepatologic and nephrologic effects of calcitriol in Syrian golden hamster (Mesocricetus auratus). Acta Biochim Pol 65: 351-358, 2018.

53. Slominski AT, Kim TK, Shehabi HZ, Semak I, Tang EK, Nguyen MN, Benson HA, Korik E, Janjetovic Z, Chen J, et al: In vivo evidence for a novel pathway of vitamin $D_{3}$ metabolism initiated by P450scc and modified by CYP27B1. FASEB J 26 3901-3915, 2012

54. Slominski AT, Kim TK, Li W, Postlethwaite A, Tieu EW, Tang EK and Tuckey RC: Detection of novel CYP11A1-derived secosteroids in the human epidermis and serum and pig adrenal gland. Sci Rep 5: 14875, 2015. 
55. Slominski AT, Li W, Kim TK, Semak I, Wang J, Zjawiony JK and Tuckey RC: Novel activities of CYP11A1 and their potential physiological significance. J Steroid Biochem Mol Biol 151: 25-37, 2015.

56. Dasari S and Tchounwou PB: Cisplatin in cancer therapy: Molecular mechanisms of action. Eur J Pharmacol 740: 364-378, 2014.

57. Marullo R, Werner E, Degtyareva N, Moore B, Altavilla G, Ramalingam SS and Doetsch PW: Cisplatin induces a mitochondrial-ROS response that contributes to cytotoxicity depending on mitochondrial redox status and bioenergetic functions. PLoS One 8: e81162, 2013.

58. Pourahmad J, Amirmostofian M, Kobarfard F and Shahraki J: Biological reactive intermediates that mediate dacarbazine cytotoxicity. Cancer Chemother Pharmacol 65: 89-96, 2009.

59. Slominski A, Semak I, Zjawiony J, Wortsman J, Li W, Szczesniewski A and Tuckey RC: The cytochrome P450scc system opens an alternate pathway of vitamin D3 metabolism. FEBS J 272: 4080-4090, 2005.

60. Aykul S and Martinez-Hackert E: Determination of half-maximal inhibitory concentration using biosensor-based protein interaction analysis. Anal Biochem 508: 97-103, 2016.

61. Kalliokoski T, Kramer C, Vulpetti A and Gedeck P. Comparability of mixed $\mathrm{IC}_{50}$ data - a statistical analysis. PLoS One 8: e61007, 2013.

62. Livak KJ and Schmittgen TD: Analysis of relative gene expression data using real-time quantitative PCR and the 2(-Delta Delta C(T)) method. Methods 25: 402-408, 2001.

63. Slominski AT, Janjetovic Z, Kim TK, Wright AC, Grese LN, Riney SJ, Nguyen MN and Tuckey RC: Novel vitamin D hydroxyderivatives inhibit melanoma growth and show differential effects on normal melanocytes. Anticancer Res 32: 3733-3742, 2012.

64. Janjetovic Z, Brozyna AA, Tuckey RC, Kim TK, Nguyen MN, Jozwicki W, Pfeffer SR, Pfeffer LM and Slominski AT: High basal NF- $\kappa \mathrm{B}$ activity in nonpigmented melanoma cells is associated with an enhanced sensitivity to vitamin D3 derivatives. $\mathrm{Br}$ J Cancer 105: 1874-1884, 2011.

65. Corazao-Rozas P, Guerreschi P, Jendoubi M, André F, Jonneaux A, Scalbert C, Garçon G, Malet-Martino M, Balayssac S, Rocchi S, et al: Mitochondrial oxidative stress is the Achille's heel of melanoma cells resistant to Braf-mutant inhibitor. Oncotarget 4: 1986-1998, 2013.

66. Florea AM and Büsselberg D: Cisplatin as an anti-tumor drug: Cellular mechanisms of activity, drug resistance and induced side effects. Cancers (Basel) 3: 1351-1371, 2011.

67. Le TYL, Ogawa M, Kizana E, Gunton JE and Chong JJH: Vitamin D Improves Cardiac Function After Myocardial Infarction Through Modulation of Resident Cardiac Progenitor Cells. Heart Lung Circ 27: 967-975, 2018.

68. Cai L, Luo L, Tang Z and Meng X: Combined antitumor effects of 1,25 dihydroxy vitamin D3 and Notch inhibitor in liver cancer. Oncol Rep 40: 1515-1524, 2018.

69. Corachan A, Ferrero H, Aguilar A, Garcia N, Monleon J, Faus A, Cervelló I and Pellicer A: Inhibition of tumor cell proliferation in human uterine leiomyomas by vitamin $\mathrm{D}$ via $\mathrm{Wnt} / \beta$-catenin pathway. Fertil Steril 111: 397-407, 2019.

70. Linos E, Swetter SM, Cockburn MG, Colditz GA and Clarke CA: Increasing burden of melanoma in the United States. J Invest Dermatol 129: 1666-1674, 2009.

71. Slominski AT, Zmijewski MA, Plonka PM, Szaflarski JP and Paus R: How UV Light Touches the Brain and Endocrine System Through Skin, and Why. Endocrinology 159: 1992-2007, 2018.

72. Haussler MR, Jurutka PW, Mizwicki M and Norman AW: Vitamin $\mathrm{D}$ receptor (VDR)-mediated actions of $1 \alpha, 25(\mathrm{OH})_{2}$ vitamin $\mathrm{D}_{3}$ : genomic and non-genomic mechanisms. Best Pract Res Clin Endocrinol Metab 25: 543-559, 2011.

73. Moukayed M and Grant WB: Molecular link between vitamin D and cancer prevention. Nutrients 5: 3993-4021, 2013.

74. Wacker M and Holick MF: Sunlight and Vitamin D: A global perspective for health. Dermatoendocrinol 5: 51-108, 2013.

75. Timerman D, McEnery-Stonelake M, Joyce CJ, Nambudiri VE, Hodi FS, Claus EB, Ibrahim N and Lin JY: Vitamin D deficiency is associated with a worse prognosis in metastatic melanoma. Oncotarget 8: 6873-6882, 2017.

76. Caini S, Boniol M, Tosti G, Magi S, Medri M, Stanganelli I, Palli D, Assedi M, Marmol VD and Gandini S: Vitamin D and melanoma and non-melanoma skin cancer risk and prognosis: A comprehensive review and meta-analysis. Eur J Cancer 50: 2649-2658, 2014.
77. Wyatt C, Lucas RM, Hurst C and Kimlin MG: Vitamin D deficiency at melanoma diagnosis is associated with higher Breslow thickness. PLoS One 10: e0126394, 2015.

78. Ogbah Z, Visa L, Badenas C, Ríos J, Puig-Butille JA, Bonifaci N, Guino E, Augé JM, Kolm I, Carrera C, et al: Serum 25-hydroxyvitamin D3 levels and vitamin D receptor variants in melanoma patients from the Mediterranean area of Barcelona. BMC Med Genet 14: 26, 2013.

79. Sinnberg T, Levesque MP, Krochmann J, Cheng PF, Ikenberg K, Meraz-Torres F, Niessner H, Garbe C and Busch C: Wnt-signaling enhances neural crest migration of melanoma cells and induces an invasive phenotype. Mol Cancer 17: 59, 2018.

80. Piotrowska A, Wierzbicka J, Nadkarni S, Brown G, Kutner A and Żmijewski MA: Antiproliferative Activity of Double Point Modified Analogs of 1,25-Dihydroxy vitamin $\mathrm{D}_{2}$ Against Human Malignant Melanoma Cell Lines. Int J Mol Sci 17: 17, 2016.

81. Wasiewicz T, Piotrowska A, Wierzbicka J, Slominski AT and Zmijewski MA: Antiproliferative Activity of Non-Calcemic Vitamin D Analogs on Human Melanoma Lines in Relation to VDR and PDIA3 Receptors. Int J Mol Sci 19: 19, 2018.

82. Field S and Newton-Bishop JA: Melanoma and vitamin D. Mol Oncol 5: 197-214, 2011.

83. Szyszka P, Zmijewski MA and Slominski AT: New vitamin D analogs as potential therapeutics in melanoma. Expert Rev Anticancer Ther 12: 585-599, 2012.

84. Al-Qatati A and Aliwaini S: Combined pitavastatin and dacarbazine treatment activates apoptosis and autophagy resulting in synergistic cytotoxicity in melanoma cells. Oncol Lett 14: 7993-7999, 2017.

85. Del Bello B, Toscano M, Moretti D and Maellaro E: Cisplatin-induced apoptosis inhibits autophagy, which acts as a pro-survival mechanism in human melanoma cells. PLoS One 8: e57236, 2013.

86. Kissel CK, Schadendorf D and Röckmann H: The altered apoptotic pathways in cisplatin and etoposide-resistant melanoma cells are drug specific. Melanoma Res 16: 527-535, 2006.

87. Wangpaichitr M, Wu C, Li YY, Nguyen DJM, Kandemir H, Shah S, Chen S, Feun LG, Prince JS, Kuo MT, et al: Exploiting ROS and metabolic differences to kill cisplatin resistant lung cancer. Oncotarget 8: 49275-49292, 2017.

88. Goldstein I, Rivlin N, Shoshana OY, Ezra O, Madar S, Goldfinger $\mathrm{N}$ and Rotter V: Chemotherapeutic agents induce the expression and activity of their clearing enzyme CYP3A4 by activating p53. Carcinogenesis 34: 190-198, 2013.

89. Ortiz de Montellano PR: Cytochrome P450-activated prodrugs. Future Med Chem 5: 213-228, 2013.

90. Lu Y and Cederbaum AI: Cisplatin-induced hepatotoxicity is enhanced by elevated expression of cytochrome P450 2E1. Toxicol Sci 89: 515-523, 2006.

91. Wierzbicka J, Piotrowska A and Zmijewski MA: The renaissance of vitamin D. Acta Biochim Pol 61: 679-686, 2014.

92. Box NF, Vukmer TO and Terzian T: Targeting p53 in melanoma. Pigment Cell Melanoma Res 27: 8-10, 2014.

93. Slominski AT, Kim TK, Hobrath JV, Oak ASW, Tang EKY, Tieu EW, Li W, Tuckey RC and Jetten AM: Endogenously produced nonclassical vitamin D hydroxy-metabolites act as 'biased' agonists on VDR and inverse agonists on ROR $\alpha$ and ROR $\gamma$. J Steroid Biochem Mol Biol 173: 42-56, 2017.

94. Slominski AT, Kim TK, Takeda Y, Janjetovic Z, Brozyna AA, Skobowiat C, Wang J, Postlethwaite A, Li W, Tuckey RC, et al: ROR $\alpha$ and ROR $\gamma$ are expressed in human skin and serve as receptors for endogenously produced noncalcemic 20-hydroxyand 20,23-dihydroxyvitamin D. FASEB J 28: 2775-2789, 2014.

95. Lin Z, Marepally SR, Goh ESY, Cheng CYS, Janjetovic Z, Kim TK, Miller DD, Postlethwaite AE, Slominski AT, Tuckey RC, et al: Investigation of 20S-hydroxyvitamin D3 analogs and their $1 \alpha-\mathrm{OH}$ derivatives as potent vitamin $\mathrm{D}$ receptor agonists with anti-inflammatory activities. Sci Rep 8: $1478,2018$.

96. Lin Z, Chen H, Belorusova AY, Bollinger JC, Tang EKY, Janjetovic Z, Kim TK, Wu Z, Miller DD, Slominski AT, et al: $1 \alpha, 20$ S-Dihydroxyvitamin D3 Interacts with Vitamin D Receptor: Crystal Structure and Route of Chemical Synthesis. Sci Rep 7: 10193, 2017.

97. Slominski AT, Kim TK, Janjetovic Z, Brożyna AA, Żmijewski MA, Xu H, Sutter TR, Tuckey RC, Jetten AM and Crossman DK: Differential and Overlapping Effects of $20,23(\mathrm{OH})_{2} \mathrm{D}_{3}$ and $1,25(\mathrm{OH})_{2} \mathrm{D}_{3}$ on Gene Expression in Human Epidermal Keratinocytes: Identification of $\mathrm{AhR}$ as an Alternative Receptor for 20,23(OH) 2 D3. Int J Mol Sci 19: 19, 2018. 
98. Kim TK, Wang J, Janjetovic Z, Chen J, Tuckey RC, Nguyen MN, Tang EK, Miller D, Li W and Slominski AT: Correlation between secosteroid-induced vitamin D receptor activity in melanoma cells and computer-modeled receptor binding strength. Mol Cell Endocrinol 361: 143-152, 2012.

99. Barutello G, Rolih V, Arigoni M, Tarone L, Conti L, Quaglino E, Buracco P, Cavallo F and Riccardo F: Strengths and Weaknesses of Pre-Clinical Models for Human Melanoma Treatment: Dawn of Dogs' Revolution for Immunotherapy. Int J Mol Sci 19: 19, 2018.

100. Kuzu OF, Nguyen FD, Noory MA and Sharma A: Current State of Animal (Mouse) Modeling in Melanoma Research. Cancer Growth Metastasis 8 (Suppl 1): 81-94, 2015.

101.Hoffman RM: Patient-Derived Orthotopic Xenograft (PDOX) Models of Melanoma. Int J Mol Sci 18: 18, 2017.
102. Kawaguchi K, Han Q, Li S, Tan Y, Igarashi K, Miyake K, Kiyuna T, Miyake M, Chemielwski B, Nelson SD, et al: Intra-tumor L-methionine level highly correlates with tumor size in both pancreatic cancer and melanoma patient-derived orthotopic xenograft (PDOX) nude-mouse models. Oncotarget 9: 11119-11125, 2018.

103. Kawaguchi K, Igarashi K, Li S, Han Q, Tan Y, Miyake K, Kiyuna T, Miyake M, Murakami T, Chmielowski B, et al: Recombinant methioninase (rMETase) is an effective therapeutic for BRAF-V600E-negative as well as -positive melanoma in patient-derived orthotopic xenograft (PDOX) mouse models. Oncotarget 9: 915-923, 2017. 